\title{
AVALIAÇÃO DE PARÂMETROS QUE INFLUENCIAM A TRANSFORMAÇÃO GENÉTICA DO Eucalyptus grandis VIA Agrobacterium
}

\author{
ALEXANDER DE ANDRADE
}

\begin{abstract}
Dissertação apresentada à Escola Superior de Agricultura “Luis de Queiroz”, Universidade de São Paulo, para obtenção do título de Mestre em Agronomia, Área de Concentração: Genética e Melhoramento de Plantas.
\end{abstract}

PIRACICABA

Estado de São Paulo - Brasil

Setembro - 2001 


\title{
AVALIAÇÃO DE PARÂMETROS QUE INFLUENCIAM A TRANSFORMAÇÃO GENÉTICA DO Eucalyptus grandis VIA Agrobacterium
}

\section{ALEXANDER DE ANDRADE \\ Engenheiro Agrônomo}

Orientador: Prof. Dr CARLOS ALBERTO LABATE

\begin{abstract}
Dissertação apresentada à Escola Superior de Agricultura “Luis de Queiroz”, Universidade de São Paulo, para obtenção do título de Mestre em Agronomia, Área de Concentração: Genética e Melhoramento de Plantas.
\end{abstract}

PIRACICABA

Estado de São Paulo - Brasil

Setembro - 2001 
Dados Internacionais de Catalogação na Publicação (CIP) DIVISÃO DE BIBLIOTECA E DOCUMENTAÇÃO - Campus “Luiz de Queiroz”/USP

Andrade, Alexander de

Avaliação de parâmetros que influenciam a transformação genética do Eucalyptus grandis via Agrobacterium / Alexander de Andrade. - - Piracicaba, 2001.

$$
82 \text { p. : il. }
$$

Dissertação (mestrado) - - Escola Superior de Agricultura Luiz de Queiroz, 2001.

Bibliografia.

1. Bactéria fitopatôgenica 2. Biolística 3. Eucalipto 4. Explante vegetal 5. Genética florestal 6. Melhoramento genético vegetal 7. Parâmetro genético 8. Transformação genética I. Título

CDD 634.9734

\section{"Permitida a cópia total ou parcial deste documento, desde que citada a fonte - $O$ autor"}


Ao meu pai pelo seu apoio incondicional. 


\section{AGRADECIMENTOS}

Ao Prof. Dr. Carlos Alberto Labate, pela oportunidade e confiança em mim depositada, pela orientação e amizade.

À Dra. Mônica T. Labate pela amizade, sugestões e auxílio na execução deste trabalho.

Aos professores do Departamento de Genética pelos ensinamentos.

À profa. Dra. Beatriz Appezzato-da-Glória do Departamento de Ciências Biológicas da ESALQ, pela orientação nas análises histológicas e ultra-estruturais.

Ao amigo Esteban por toda a ajuda e sugestões durante a realização deste trabalho e no decorrer do curso.

À técnica Marly K. M. Soares do Departamento de Ciências Biológicas pela ajuda no desenvolvimento das técnicas de microscopia.

Aos amigos do laboratório, Guilhermo, Altamir, Gisele, Valéria, Marcelo, Rui, Raqueline, Leticia, Daniela, Daniele, Paulo, Paulo Barja, Gunta, Raphael, Juliano, Ana Paula, Carol, Karen, Aline, João, Felipe, Erica e Fernanda pela agradável convivência e constante troca de informações.

Ao técnico, Jose Carmezini e a auxiliar de laboratório Palmira Cogo, ambos do Laboratório de Genética Fisiológica.

À CAPES pela concessão da bolsa.

A todos que, de alguma forma, contribuíram para a realização desta dissertação 


\section{SUMÁRIO}

Página

ABREVIATURAS e SÍMBOLOS.......................................................... VII

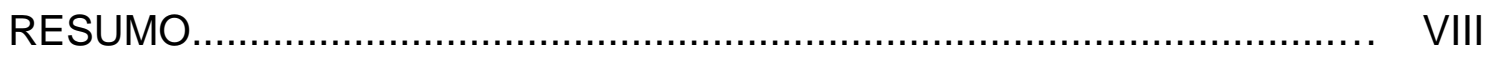

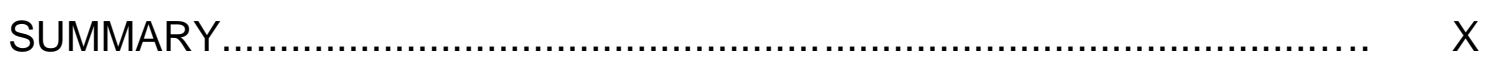

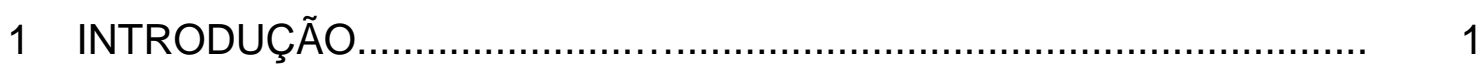

2 REVISÃO DE LITERATURA......................................................... 3

2.1 O gênero Eucalyptus................................................................ 3

2.2 Importância econômica do eucalipto ............................................. 5

2.3 Transformação genética................................................................ 7

2.4 Transformação genética via biobalística.......................................... 9

2.5 Transformação genética via Agrobacterium .................................... 10

$\begin{array}{lll}2.6 \text { Uso da sonicação na transformação genética via Agrobacterium ... } & 15\end{array}$

2.7 Métodos de seleção de plantas transformadas.................................. 18

3 MATERIAL E MÉTODOS ................................................................ 20

3.1 Material vegetal................................................................. 20

3.2 Indução de acumulo de gemas..................................................... 21

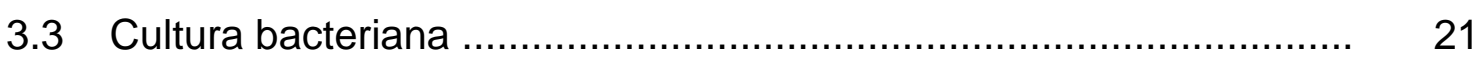

3.4 Avaliação da expressão transitória do gene uidA ........................... 23

3.5 Transformação por biobalística.................................................... 24

3.6 Estabilidade e expressão da atividade da ß-glucuronidase............... 26

3.7 Distância do alvo............................................................................. 26

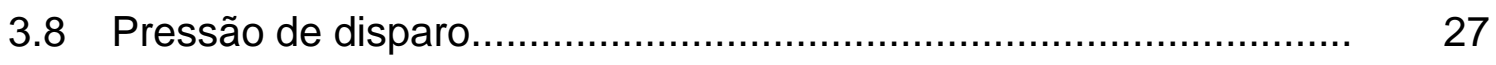

3.9 Temperatura de co-cultivo....................................................... 27

3.10 Caracterização anatômica do explante......................................... 28 
3.11 Localização da região de expressão do gene uidA........................ 28

3.12 Susceptibilidade de espécies de Eucalyptus a agentes seletivos... $\quad 30$

3.13 Susceptibilidade de diferentes progênies de

Eucalyptus a agentes seletivos..................................................... 30

3.14 Seleção de clones com alta taxa de regeneração e alta susceptibilidade a agentes seletivos.............................................. 31

3.15 Seleção de clones susceptíveis àtransformação............................ 32

3.16 Aparelho de sonicação............................................................ 32

3.17 Efeito do tempo de sonicação................................................... 33

3.18 Efeito da pós sonicação............................................................ 33

3.19 Análise dos dados..................................................................... 34

4 RESULTADOS e DISCUSSÃO...................................................... 35

4.1 Determinação da estabilidade da expressão do gene uidA ….......... 35

4.2 Determinação da melhor distância do alvo

para o bombardeamento.................................................................... 37

4.3 Bombardeamento com diferentes pressões de disparo.................... 38

4.4 Temperatura de co-cultivo........................................................ 40

4.5 Caracterização anatômica do explante e localização da região com expressão do gene uidA............................................................... 42

4.6 Susceptibilidade de diferentes espécies de Eucalyptus a agentes seletivos

4.7 Susceptibilidade de diferentes progênies de Eucalyptus a agentes seletivos.

4.8 Seleção de clones susceptíveis a agentes seletivos......................... 53

4.9 Seleção de clones susceptíveis àtransformação.............................. 56

4.10 Efeito do tempo de sonicação.................................................... 57

4.11 Efeito da pós sonicação............................................................. 60

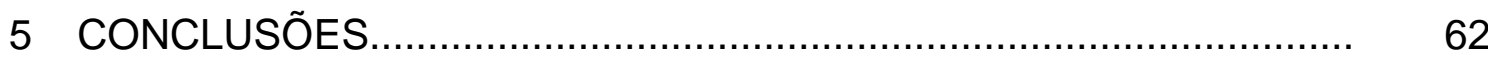

REFERÊNCIAS BIBLIOGRÁFICAS.................................................... 64

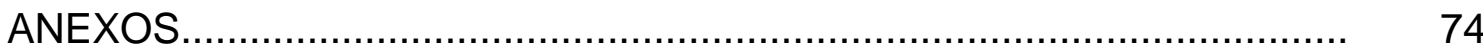




\section{ABREVIATURAS e SÍMBOLOS}

$\begin{array}{ll}\mu \mathrm{Em}^{-2} \mathrm{~s}^{-1} & \text { Micro Einstein por metro quadrado por segundo } \\ \mu \mathrm{m} & \text { Micrometro } \\ \mu \mathrm{M} & \text { Micromolar } \\ \text { BAP } & \text { 6-Benzilaminopurina } \\ \mathrm{mgL}^{-1} & \text { Miligramas por litro } \\ \text { ANA } & \text { Ácido Naftaleno Acético } \\ \text { T-DNA } & \text { Região do DNA plasmidial de Agrobacterium que } \\ & \text { é transferido æ̀s células vegetais } \\ \text { uidA } & \text { Gene que codifica a enzima B-glucuronidase } \\ \text { X-gluc } & \text { Ácido 5-bromo-4-cloro-3-indolil-B-D-glucurônico } \\ \text { CaMV } & \text { Vírus do mosaico da couve-flor } \\ \text { O.D } & \text { Densidade ótica } \\ \text { PSI } & \text { Libra(s) por polegada quadrada } \\ \text { BOD } & \text { Estufa incubadora } \\ \text { rpm } & \text { Rotações por minuto } \\ \text { TDZ } & \text { Thidiazuron }\end{array}$




\title{
AVALIAÇÃO DE PARÂMETROS QUE INFLUENCIAM A TRANSFORMAÇÃO GENÉTICA DO Eucalyptus grandis VIA Agrobacterium
}

\author{
Autor: Alexander de Andrade \\ Orientador: Prof. Dr. Carlos Alberto Labate
}

\section{Resumo}

O trabalho teve como objetivo otimizar a metodologia de transformação de plantas de Eucalyptus grandis; uma importante espécie florestal amplamente cultivada no Brasil. Foram estudadas a transformação por agrobiobalística de explantes com acúmulo de gemas axilares e do SAAT ("sonication-assisted Agrobacterium mediated transformation"). Ambas as técnicas causam microferimentos nos explantes aumentando a penetração da Agrobacterium nos tecidos vegetais. Na agrobiobalística o explante é submetido ao bombardeamento com micropartículas seguida por inoculação com a bactéria; enquanto que no SAAT o explante é submetido à sonicação por breves períodos de tempo na presença da bactéria. Os experimentos de transformação foram avaliados pela analise da expressão transitória do gene repórter uidA. Os parâmetros estudados na transformação por agrobiobalística foram: pressão de disparo ( pressão do gás hélio), distância de vôo das micropartículas, estabilidade da expressão do gene uidA e temperatura de cocultivo. As freqüências mais elevadas da expressão da B-glucuronidase foram observadas utilizando 1350 PSI de gás hélio, 9,5 cm de distância de vôo dos microprojéteis e temperatura de $26^{\circ} \mathrm{C}$ durante o co-cultivo. Para otimizar a 
transformação de explantes com acúmulo de gemas axilares foi realizado um estudo histológico, o qual permitiu constatar que as áreas meristemáticas estão localizadas na superfície do explante. O meristema é formado pela rediferenciação de células da epiderme e das primeiras camadas do parênquima cortical caracterizando sua origem exógena. A localização histológica do produto da expressão do gene repórter uidA mostrou que esta expressão ocorre apenas em células já diferenciadas, não sendo encontrada durante os tratamentos com células meristemáticas. Para realizar os ensaios com SAAT foi selecionado previamente um clone com características favoráveis àtransformação: alta taxa de regeneração, susceptibilidade a agentes seletivos e à transformação por Agrobacterium. A maior taxa de plantas que apresentaram atividade da B-glucuronidase foram observadas utilizando-se 60 segundos de sonicação; tempos superiores a este causaram um comprometimento da regeneração do explante. A sonicação adicional, após a sonicação preliminar do explante, juntamente com a bactéria, melhora a eficiência do processo de transformação. Os resultados demonstram que o uso de SAAT é viável na transformação de eucalipto com Agrobacterium. 


\title{
EVALUATION OF PARAMETERS WHICH AFFECT THE Agrobacterium MEDIATED GENETIC TRANSFORMATION OF Eucalyptus grandis
}

\author{
Author: Alexander de Andrade \\ Adviser: Prof. Dr. Carlos Alberto Labate
}

\section{Summary}

The research project aimed the establishment of a method for genetic transformation of Eucalyptus grandis; an important and widely planted forestry tree in Brazil. Two techniques of transformation were tested: agrobiolistic of explants with accumulation of meristematic cells and SAAT ("sonication-assisted Agrobacterium mediated transformation"). Both systems of transformation aim to produce micro wounds in the explants in order to increase the Agrobacterium penetration in the tissues. In the case of agrolistica the explant was previously submitted to micro projectile bombardment, followed by bacteria inoculation. On the other hand in the SAAT technique the explante is submitted to short periods (few seconds) of sonication together with the bacteria. Transformation was evaluated by measuring the expression of the reporter gene uid $A$ which codes the B-glucuronidase enzyme. Several parameters were tested for agrobiolistic such as, gas pressure (helium), flight distance of micro projectiles, gene expression of the uidA, co-cultivation temperature. The highest values of $B$ glucuronidase were observed for $1350 \mathrm{PSI}, 9.5 \mathrm{~cm}$ from target and $26^{\circ} \mathrm{C}$ for cocultivation. A histological analyze was carried out to check it the meristematic 
tissues were being transformed. The results showed that the meristematic tissues were localized in the surface of the explante. The meristem is formed by the dedifferentiation of epidermal cells and the first layers of the cortical parenchyma indicating its exogenous origin. The histological location of the reporter gene uidA showed that the expression occurs only in cells already differentiated, and not in meristematic cells. For SAAT experiments a clone was previously selected for favorable characteristic of transformation: high rate of regeneration, susceptibility of selective agents and to Agrobacterium transformation. The highest rate of B-glucuronidase activity were observed for $60 \mathrm{~s}$ of sonication; higher sonication time reduced the efficiency of regeneration. Additional sonication, following a preliminary sonication of explante, in the presence of the bacteria, improved the efficiency of transformation. The results provided evidence the SAAT is a viable technique for Eucalyptus transformation via Agrobacterium. 


\section{INTRODUÇÃO}

O eucalipto é a árvore com maior área plantada nas regiões de clima tropical, sendo que o Brasil é o maior produtor mundial da espécie Eucalyptus, com uma área de cultivo estimada em 2,965,880 ha (SBS Silvicultura, 2000).

O Eucalyptus possui um grande destaque no cenário da silvicultura no Brasil e no mundo, devido a sua adaptabilidade, rapidez no crescimento, aliado à produção de fibras e polpa de madeira de alta qualidade a um baixo custo. Essas vantagens vêm atraindo cada vez mais, grandes interesses empresariais, principalmente da industria de papel e celulose.

A indústria brasileira de papel e celulose, tem apresentado, nos últimos anos um crescimento acelerado tornando-se em 1994 a sétima maior produtora de celulose, e décima primeira em produção de papel, sendo o Eucalyptus a principal espécie usada como matéria prima. Seu grande uso na indústria florestal brasileira deve-se, principalmente ao investimento em programas de melhoramento genético e à aplicação de técnicas de propagação clonal (Cruz et al., 1988).

O melhoramento tradicional apresenta limitações pois requer muito tempo para se obter resultados, com o processo de 
sucessivos cruzamentos dirigidos. Essas limitações são impostas pelo longo ciclo de vida das espécies arbóreas.

A biotecnologia, através da transformação genética, possibilita a introdução de genes de interesse em uma única geração podendo alterar características como conteúdo de lignina, resistência a insetos, resistência à herbicida e alteração de rotas metabólicas. A aplicação desta nova tecnologia no melhoramento do Eucalyptus pode levar a um aumento de produtividade, atendendo a uma demanda crescente por produtos florestais de qualidade com baixo custo de produção.

Este trabalho tem como objetivo desenvolver um protocolo de transformação de Eucalyptus grandis via Agrobacterium. Foram avaliadas a transformação por agrobiobalística e por SAAT ("sonication assisted Agrobacterium mediated transformation"). Na agrobiobalística foram utilizados explantes com acúmulo de gemas axilares induzidas por hormônios. Este explante foi escolhido por apresentar uma alta taxa de regeneração, produzindo até 15 brotos por plântula. Para auxiliar a transformação via agrobiobalística foi realizado um estudo anatômico e histológico do material. Na avaliação do método SAAT foi usado como explante um clone previamente selecionado que apresenta características favoráveis à transformação como alta taxa de regeneração, susceptibilidade a bactéria e a agentes seletivos. 


\section{REVISÃO DE LITERATURA}

\subsection{O Gênero Eucalyptus}

O gênero Eucalyptus pertence à família Myrtaceae, subgênero Symphyomyrtus e é composto pôr cerca de 600 espécies, 24 subespécies, 24 variedades e vários híbridos naturais, podendo ser encontrado desde a forma arbustiva até árvores de grande porte, distribuídas predominantemente em regiões tropicais e subtropicais. Possui como centro de origem a Austrália e regiões próximas como Timor, Indonésia, Papua Guiné, Molucas, Irian Jaya e sul das Filipinas, em uma faixa compreendida entre latitudes $9^{\circ} \mathrm{N}$ e $44^{\circ} \mathrm{S}$ (Eldridge et al., 1993).

O eucalipto é atualmente cultivado predominantemente em regiões de clima tropical e subtropical, entre as latitudes de $40^{\circ} \mathrm{Ne}$ $45^{\circ} \mathrm{S}$, em altitudes que variam de 30 a 1000 metros, possui espécies adaptadas a diversas condições de clima e solo, inclusive àqueles com salinidade de 2 a $3 \%$ (Cresswell et al., 1985).

O rápido crescimento (média de $45 \mathrm{~m}^{3} / \mathrm{ha}$ por ano em plantios clonais), associado àprodução de fibras e polpa de madeira de alta qualidade, com baixo custo sobre um curto período (5 - 7 anos), num regime que permite até 3 rotações sucessivas $e$ econômicas, com ciclo de até 21 anos, são as principais razões do 
extensivo uso do Eucalyptus em reflorestamentos comerciais em várias partes do mundo (Ho et al., 1998).

O eucalipto é a espécie arbórea com maior área plantada nas regiões de clima tropical, tendo como maiores produtores, o Brasil, a Índia, África do Sul, Portugal, Angola, Espanha e China. A ótima adaptação do eucalipto à condições de solo e clima levaram o Brasil a tornar-se o maior produtor mundial, possuindo uma área estimada em 2,965,880 ha (Quoirin \& Vieira, 1995). Os principais estados brasileiros produtores de eucalipto são: Minas Gerais, São Paulo e Rio Grande do Sul.

O interesse no melhoramento genético de eucalipto aumentou com a importância econômica das plantações comerciais, o que resultou no desenvolvimento de programas próprios para atender às necessidades de cada região. Graças ao intenso trabalho realizado por melhoristas nas últimas décadas, o Brasil possui hoje um dos mais importantes bancos de germoplasma do gênero Eucalyptus, com alta produtividade e adaptabilidade ao nosso ambiente.

Com uma demanda crescente de produtos florestais e o interesse pela manutenção de florestas nativas, há a necessidade constante de desenvolvimento de técnicas visando o aumento da produtividade das florestas. O melhoramento de plantas envolve dois componentes importantes: geração de tipos úteis de variação de natureza genética e epigenética através do melhoramento e seleção, manutenção e multiplicação de caracteres desejáveis, 
através de métodos de propagação sexual e assexual (Mantell, 1994).

Os principais obstáculos na prática do melhoramento genético de espécies florestais são: o tempo necessário para completar um ciclo de seleção e recombinação de indivíduos para características quantitativas e que se expressam somente em idades mais avançadas, e a dificuldade em selecionar de uma forma eficiente ao nível de indivíduo (Quoirin \& Vieira,1995).

A aplicação comercial da engenharia genética em eucalipto requer não apenas o desenvolvimento de um sistema eficiente de transferência de genes, mas também técnicas que possam ser usadas em escala comercial para propagar vegetativamente transformantes elites (Mullins et al., 1997).

\subsection{Importância econômica do eucalipto}

O Brasil ocupa hoje a $7^{\circ}$ posição mundial na produção de celulose e a $12^{\circ}$ colocação como fabricante de papel. O setor brasileiro de papel e celulose contribui de forma relevante para o desenvolvimento do País, em termos de geração de renda, tributos, empregos e divisas, bem como de promoção do desenvolvimento regional (Bracelpa, 2000).

O mercado interno do setor de base florestal brasileiro gera receitas da ordem de US\$20 bilhões, 700 mil postos de trabalho diretos e 2 milhões de indiretos. Em 1999 gerou US\$ 2 bilhões em 
impostos, com uma participação de $4 \%$ no PIB nacional, exportando US\$ 3,5 bilhões, referente a $7 \%$ das exportações nacionais, sendo que a celulose de eucalipto é o produto de base florestal que possui a participação mais expressiva no mercado mundial representando 5,2\% dos negócios internacionais.

Pesquisas realizadas por institutos internacionais indicam que a demanda mundial de celulose deverá crescer a uma taxa média anual de 2,7 \%. Estas projeções abrem excelentes perspectivas para que as empresas brasileiras retomem seus programas de investimento e participem deste crescimento da demanda mundial de papel e celulose.

Estudos realizados por consultorias internacionais sobre a competitividade da indústria brasileira de papel e celulose, apresentaram ao governo um novo programa nacional de investimentos da ordem de US $\$ 6,6$ bilhões para o período de 2000 a 2005, destinado a expandir a área florestal, bem como à ampliação e modernização de sua capacidade de produção. A concretização desses investimentos vai possibilitar o aumento de $45 \%$ na produção de celulose, de 7,7 para 11,2 milhões de toneladas, e de $17 \%$ na produção de papel, aumentando de 7,8 para 9,1 milhões de toneladas. Dessa forma poderá assegurar 0 pleno atendimento do mercado interno e o crescimento das exportações, principalmente de celulose.

Com uma exportação prevista para o final de 2005 de US\$ 3,8 bilhões, o setor apresentará um superávit da ordem de US\$2,8 bilhões na balança comercial. Esse grande programa de 
investimento depende de condições de competitividade para ser realizado ou seja, é necessário que a indústria brasileira de papel e celulose disponha de isonomia com seus concorrentes internacionais.

O desafio para o setor de papel e celulose nos próximos anos, não é apenas o de investimentos na área industrial, mas também de aumento da produtividade. A biotecnologia através da propagação clonal tem contribuído com o aumento da produtividade e da uniformidade da área cultivada. Técnicas como a transformação genética, aliada ao melhoramento convencional, podem contribuir significativamente para 0 aumento do desenvolvimento vegetativo e a biomassa das plantas, atendendo com isso a uma demanda crescente de papel e celulose.

\subsection{Transformação genética}

O uso da engenharia genética para a introdução de genes em plantas é uma ferramenta muito importante no melhoramento vegetal. Espécies que apresentam um longo ciclo como as frutíferas e agroflorestais, podem ser beneficiadas pela manipulação genética.

A manipulação genética permite que em um curto espaço de tempo possa-se introduzir genes de interesse em cultivares de alto valor comercial, eliminando com isso, a necessidade de cruzamentos que em programas de melhoramento convencional podem durar anos. 
O desenvolvimento da transformação genética tem possibilitado a quebra de barreiras como a incompatibilidade sexual existente entre indivíduos, possibilitando a transferência de genes entre organismos geneticamente distantes, ampliando assim consideravelmente, a formação de novas combinações que pelo método natural são impossíveis de ocorrer.

$\mathrm{Na}$ literatura encontramos diferentes relatos, além da transformação de células vegetais e animais (Zelenin et al., 1989) de organelas como cloroplastos (Boynton et al., 1988; Svab et al., 1990); mitocôndria (Fox et al., 1988) e de procariontes (Smith et al., 1992).

A transformação genética utiliza duas estratégias para realizar a transferência de genes em plantas: forma direta e indireta.

- Na transferência direta, o principal método é o da biobalística (Sanford et al., 1993).

- Na transferência indireta, utiliza-se um vetor para promover a transferência do gene. $O$ principal vetor usado atualmente é a Agrobacterium tumefaciens (Chilton et al., 1977). 


\subsection{Transformação genética via biobalística}

A biobalística, também conhecida como método de bombardeamento com micropartículas ou aceleração de partículas é um processo que emprega microprojéteis com alta velocidade para inserir ácidos nucléicos e outras substâncias em diferentes órgãos, tecidos que em geral não dependem do genótipo usado (Klein et al., 1987; Sanford, 1990)

A transformação por biobalística é uma técnica versátil, podendo ser utilizada para transformação de diferentes tipos de tecidos, órgãos e células em geral independente do genótipo, podendo ser realizada em suspensão de células, calos, embriões imaturos, partes de embriões maduros, meristemas, pedaços de folhas, pólen e micrósporo. Espécies agronômicas consideradas recalcitrantes para a transferência de genes via Agrobacterium têm sido transformadas com o auxilio desta tecnologia.

O microprojétil usado pela biobalística pode ser definido como uma micropartícula de metal com alta densidade (ouro e tungstênio) mais ou menos esférica com um diâmetro de 0,4-2 $\mu \mathrm{m}$ capaz de ser submetido a altas velocidades, penetrando na célula ou no tecido de uma maneira não letal, com o objetivo de transportar a molécula de DNA para o interior da célula (Sanford et al., 1990).

De modo geral a transformação de meristemas apicais e células embriogênicas por biobalística tem demonstrado uma maior eficiência na obtenção de plantas transgênicas. A transformação de tecidos meristemáticos por meio dessa técnica apresenta a 
vantagem de evitar a ocorrência de variação somaclonal decorrente da cultura de calos.

Uma variação desta tecnologia é a utilização dessa técnica em associação com a transformação via Agrobacterium. Nesse caso o bombardeamento é utilizado para provocar a indução de macro e microferimentos no tecido vegetal, que libera compostos fenólicos e por sua vez, mobiliza a transferência do T-DNA para a célula hospedeira. A técnica tem a vantagem de aumentar a freqüência de transformantes, uma vez que os microferimentos não prejudicam a célula vegetal e são suficientes para a indução da transferência do T-DNA. Atualmente este novo método de transformação é conhecido como Agrobiobalística (Bidney et al., 1992; Brasileiro et al., 1996)

\subsection{Transformação genética via Agrobacterium}

A Agrobacterium tumefaciens é uma bactéria de solo patogênica para um amplo número de espécies, especialmente as dicotiledôneas, causando a formação de tumores na região de infecção, dando origem a uma doença conhecida como galha da coroa (Smith \& Townsend, 1907). A proliferação dos tecidos que formam os tumores fornece aminoácidos (opinas) à bactéria, que são uma importante fonte de carbono e nitrogênio, æ̀s custas da planta hospedeira (Hellens et al., 2000). 
O estudo da doença causada pela Agrobacterium tumefaciens demonstrou que o crescimento dos tumores é o resultado da expressão de genes de um segmento de DNA da bactéria que é transferido e estavelmente integrado no cromossomo da planta (Chilton et al., 1977).

Durante o processo de infecção, um segmento específico do DNA conhecido como T-DNA, é transferido da bactéria para a célula hospedeira e inserido no genoma nuclear (Hansen \& Wright, 1999).

O T-DNA da bactéria é delimitado por duas bordas, à direita e a esquerda, formadas por 25 pares de bases conhecidas como "seqüências repetidas", entre as quais encontram-se os genes oncogênicos que induzem a formação de tumores e a biossíntese de opinas. Estes genes de origem bacteriana são funcionais apenas em células de plantas. A remoção dos genes oncogênicos do TDNA não diminui a capacidade da bactéria de transferi-lo e integrálo no genoma da célula hospedeira; porém, inibe a formação de tumores. Raças de Agrobacterium que não apresentam plastídios Ti oncogênicos são conhecidas como desarmadas. O principal componente para realizar a transferência com sucesso do T-DNA são os genes localizados na região vir, podendo residir em plasmídios separados (Hellens et al., 2000). A região vir possui um grupo de aproximadamente 35 genes que são responsáveis pelo processo que envolve desde o reconhecimento do hospedeiro pelo patógeno até a inserção do segmento de T-DNA no núcleo da célula hospedeira. 
A interação entre Agrobacterium e planta envolve uma complexa série de sinais químicos de comunicação entre o patógeno e o hospedeiro. Os sinais incluem açúcares neutros, compostos fenólicos e opinas. Estes compostos fenólicos servem como indutores dos genes vir das bactérias, podendo estar envolvidos em processos como a produção de fitoalexinas e biossíntese de lignina em plantas. Assim a Agrobacterium utiliza parte do mecanismo de defesa como forma de um mecanismo sinalizador de uma planta potencialmente susceptível à infecção (Winans, 1992; Charles et al., 1992; Hooykaas \& Beijersbergen, 1994).

Compostos fenólicos como a acetoseringona (Stachel et al., 1985; Bolton et al., 1986; Engstrom et al., 1987; Xu et al., 1993; Dye et al., 1997) são percebidos por proteínas sensoras, as VirA, embora exista evidência da participação de proteínas cromossômicas no processo de reconhecimento de fenóis (Hess et al., 1991). A autofosforilação das proteínas VirA e a subseqüente fosforilação das proteínas VirG (Jin et al., 1990a; Jin et al., 1990b) resulta na ativação da transcrição dos genes vir. Muitas proteínas Vir são diretamente envolvidas no processamento do T-DNA de plasmídios Ti e na subseqüente transferência do T-DNA da bactéria para a célula da planta (Stachel et al., 1986; Jayaswal et al., 1987; Steck et al., 1990; Filichkin \& Gelvin, 1993; Jasper et al., 1994; Scheiffele et al., 1995).

As espécies vegetais diferem grandemente em sua susceptibilidade àinfecção causada por Agrobacterium tumefaciens 
ou Agrobacterium rhizogenes (Decleene \& Deley, 1976; Anderson \& Moore, 1979). Mesmo dentro de espécies, cultivares ou ecótipos pode haver diferentes níveis de susceptibilidade a tumorogênese por uma raça particular de Agrobacterium. Esta diferença tem sido observada em milho (Schlappi \& Hohn, 1992), legumes (Hood et al., 1987; Schroeder et al., 1993), aspen (Beneddra et al., 1996), curcubitaceas (Smarrelli et al., 1986), pinus (Bergmann \& Stomp, 1992), tomate (Vanroekel et al., 1993), arabidopsis (Nam et al., 1997), eucalipto (Machado et al., 1997; Mullins et al., 1997) e outras espécies.

Embora algumas diferenças na freqüência de transformação possam ser atribuídas aos fatores ambientais e fisiológicos, a base genética da susceptibilidade à transformação por Agrobacterium tem sido claramente verificada em algumas espécies de plantas. Muitos trabalhos demonstram que vários tecidos, órgãos e tipos de células dentro de uma planta podem diferir em sua susceptibilidade à transformação por Agrobacterium (Robbs et al., 1991; Bailey et al., 1994; Mauro et al., 1995; Nam et al., 1997).

Avaliando a expressão transitória do gene uidA, Ritchie et al. (1993) demonstraram que em milho, a transformação ocorre em segmentos do mesofilo originados da região meristemática intercalar. Análises histoquímicas de secções desta região indicam que a atividade GUS ocorre apenas no cilindro vascular. Alguma atividade GUS também foi localizada na folha e no cotilédone, mas não no broto apical. Já Shen et al. (1993) observaram expressão do 
gene uidA localizada apenas nas folhas e cotilédones de brotos de milho. Schlappi \& Hohn (1992) demonstraram que embriões de milho são competentes àtransformação apenas quando começam a diferenciar-se.

Dekathen \& Jacobsen (1995) demonstraram que apenas células diferenciadas próximas do sistema vascular de cotilédone e regiões do epicótilo de Pisum sativum são susceptíveis à transformação por Agrobacterium.

Em Arabidopsis apenas células diferenciadas do mesofilo da folha e do cotilédone são susceptíveis à transformação. No tecido da raiz as células competentes são encontradas em periciclo desdiferênciado. Estas células têm como característica comum sua morfologia: são pequenas, isodiamétricas possuem núcleo proeminente e um citoplasma denso (Sangwan et al., 1992).

O sistema de transformação usando Agrobacterium tumefaciens é bastante atrativo pois exige um custo mínimo em equipamentos e um protocolo relativamente fácil. Plantas transgênicas obtidas por este método, muitas vezes, possuem uma única cópia inserida, evitando com isso problemas como silênciamento gênico, bastante comum em sistemas de transformação direta. 


\subsection{Uso da sonicação na transfo rmação genética via} Agrobacterium

O ferimento é um passo imprescindível na transformação mediada pela Agrobacterium permitindo a infecção de tecidos da planta pela bactéria. Pois o tecido ferido muitas vezes produz indutores do processo de transferência do T-DNA (Stachel et al., 1985). A transformação pode ser aumentada pela adição de acetoseringona para induzir a expressão dos genes vir ou pelo uso de raças de Agrobacterium altamente virulentas que possuem genes vir constitutivos (Hansen et al., 1994).

O método que provoca o ferimento pode ser uma simples injuria causada durante o curso normal de preparo do explante (Horsch et al., 1985) ou por métodos mais sofisticados como: bombardeamento com micropartículas (Bidney et al., 1992), uso de seringas com Agrobacterium ou mais recentemente o uso de sonicação (Trick \& Finer, 1997).

O primeiro relato do uso de sonicação em plantas foi realizado por Lehmann em 1954 o qual expôs raízes de Allium cepa a uma freqüência de 0,8 e 1,0 MHz de ultra-som. Após a sonicação observou-se a presença de desenvolvimento de pequenas zonas de destruição. A reação biológica foi revertida quando as raízes eram sonicadas em ambiente pressurizado, indicando que o dano era induzido por cavitação do gás intracelular encontrado nas células de plantas. 
Miller et al. (1974) registraram uma ruptura localizada na parede de células corticais na zona de elongação de raízes primárias de Vicia faba em resposta ao ultra-som. Acredita-se que o efeito do ultra-som possa ser provocado por cavitação acústica particularmente de baixa energia. Dois fenômenos de cavitação acústica foram descritos: A primeira cavitação é conhecida como transitória onde pequenas bolhas são formadas e oscilam seu tamanho até finalmente explodirem, gerando ondas de alta pressão e temperatura durante o estágio final do colapso. A alta pressão de onda que emana da bolha é capaz de causar efeitos mecânicos destruindo ou machucando o material como células e macromoléculas (Suslick, 1988).

A segunda cavitação é conhecida como estável. Nela ocorrem rápidas oscilações no tamanho da bolha, causando um violento fluxo de fluido que rodeia a bolha em um processo conhecido como "microstreaming". A alta velocidade do fluxo de fluido que rodeia a bolha resulta em uma destruição mecânica no tecido da planta e em macromoléculas (Frizzel, 1988).

Não é bem claro atualmente se a implosão ou "microstreaming" responsáveis pelos microferimentos resultam da cavitação transitória ou estável. Tratamentos de longa duração com sonicação causam micro ferimentos com tamanhos que podem variar de $1 \mu \mathrm{m}$ a $1 \mathrm{~mm}$ (Trick \& Finer, 1998).

Zhang et al. (1991) através da sonicação de pequenos pedaços de flhas de tabaco $(4 \times 8 \mathrm{~mm})$ com DNA registraram transformação estável. 
Trick \& Finer (1997) descreveram uma nova tecnologia baseada na transformação com Agrobacterium, que pode ser usada para diversos grupos de plantas como dicotiledôneas, monocotiledôneas e gimnospermas. Esta técnica é atualmente conhecida como 'Sonication-Assisted-Agrobacterium-MediatedTransformation' (SAAT) e envolve a exposição do tecido da planta a breves períodos de ultra-sonicação em presença da Agrobacterium. Estudos com microscopia eletrônica e de luz revelaram que 0 tratamento com SAAT produz pequenas e uniformes fissuras e canais por todo o tecido, permitindo um acesso fácil da Agrobacterium para infectar tecidos internos. Experimentos têm demonstrado que o número de ferimentos é maior quando aumentase o tempo de duração do tratamento com SAAT.

A análise histológica de tecidos tratados com SAAT revelaram uma grande colonização bacteriana em células do tecido epidermal e subepidermal. Em tecidos que não recebem tratamento com SAAT, pode-se observar a presença de células bacterianas apenas na superfície dos tecidos. O método SAAT tem demonstrado um aumento da eficiência de transformação transitória em diferentes tecidos de plantas incluindo folhas, cotilédones imaturos, embriões zigóticos e somáticos, raízes, caules, gemas apicais, plântulas e em suspensão de células embriogênicas.

Ao trabalharem com soja Trick \& Finer (1998) verificaram que o uso de Agrobacterium sem sonicação resulta em uma baixa expressão transitória GUS em cultura de células em suspensão. Quando Agrobacterium foi utilizada conjuntamente com a sonicação, 
a transformação transitória foi expressivamente aumentada. Em diferentes tecidos de soja observaram um aumento de cerca de quatorze vezes na expressão transitória da ß-glucuronidase.

Santarem et al. (1998) trabalhando com cotilédones imaturos de soja observaram que o uso de SAAT melhorou a eficiência de transformação transitória destes explantes.

\subsection{Métodos de seleção de plantas transformadas}

A transformação genética requer um sistema que possibilite a seleção apenas das células transformadas. Rotineiramente são utilizados genes conhecidos como marcadores de seleção, de origem vegetal, bacteriana ou de insetos. Esses genes marcadores de seleção produzem proteínas com atividades enzimáticas que conferem à célula transformada resistência a um determinado substrato, permitindo que ela cresça. $O$ gene marcador pode ser o próprio gene de interesse ou um que irá conferir resistência a antibióticos ou herbicidas nas células transformadas (Schell et al., 1983; Sawahel, 1994; Wilmink et al., 1993).

O gene nptll (Schell et al., 1983; Fraley et al., 1983; Herrera-Estrella et al., 1983; Bevan et al., 1983) é responsável pela produção da enzima neomicina fosfotransferase II (NPTII). Esse gene é amplamente usado como marcador de seleção na transformação de plantas (Fraley et al., 1983). Nesse caso a enzima neomicina fosfotransferase (NPTII; EC 2.7.1.95) inativa 
diferentes antibióticos do grupo dos aminoglicosilados pela fosforilação do radical 3 '-OH, que incluem; canamicina, geneticina (G418), neomicina e paramomicina. A canamicina é o antibiótico mais freqüentemente utilizado para a seleção de plantas transgênicas com o gene de resistência NPTII (John L., 1993).

A resposta do eucalipto a diferentes antibióticos do grupo dos aminoglicosilados é muito variável e dependente da espécie (González et al., 2000).

Serrano et al. (1996) usando $100 \mathrm{mgL}^{-1}$ de canamicina, obtiveram uma boa resposta na seleção de calos transformados de Eucalyptus globulus. Resposta similar foi observada por Moralejo et al. (1998) usando $75 \mathrm{mgL}^{-1}$ de canamicina para selecionar plantas transformadas de Eucalyptus globulus.

Ho et al. (1998) verificaram que a concentração de 20 $\mathrm{mgL}^{-1}$ de canamicina inibiu significativamente a formação de calos de Eucalyptus camaldulensis. $O$ uso de concentrações acima de 40 $\mathrm{mgL}^{-1}$ causou intumescimento dos hipocótilos inibindo a formação de calos, que oxidaram-se.

Já Mullins et al. (1997) trabalhando com diferentes clones de Eucalyptus camaldulensis verificaram que a concentração de 9 $\mathrm{mgL}^{-1}$ de canamicina foi capaz de inibir a regeneração de brotos que não estavam transformados. 


\section{MATERIAL E MÉTODOS}

Os experimentos foram conduzidos no Laboratório de Genética Fisiológica, Departamento de Genética e Melhoramento de Plantas e o estudo histológico e anatômico do explante foi realizado no Laboratório de Microscopia do Departamento de Ciências Biológicas, ESALQ- USP.

\subsection{Material vegetal}

Sementes de eucalipto gentilmente cedidas pela Companhia Suzano de Papel e Celulose, foram desinfectadas em fluxo laminar com álcool etílico $70 \%$ (v/v) durante 15 minutos e em hipoclorito de sódio $2 \%(\mathrm{v} / \mathrm{v})$ por 10 minutos, sendo em seguida lavadas por três vezes em água destilada estéril e colocadas para germinar em meio MS (Murashige \& Skoog, 1962), contendo 2\% $(\mathrm{v} / \mathrm{v})$ de sacarose, 0,6 \% (v/v) de Agar (Merck) e pH 5,8. A germinação ocorreu em sala de cultura de tecidos sob fotoperíodo de 16 horas de luz $\left(30 \mu \mathrm{Em}^{-2} \mathrm{~s}^{-1}\right)$ e 8 horas de escuro a uma temperatura de $26 \pm 2^{\circ} \mathrm{C}$. 


\subsection{Indução de acúmulo de gemas}

A indução da formação de acúmulo de gemas axilares foi realizada com plântulas de eucalipto com 30 dias, germinadas em meio MS, descritas conforme ítem 3.1. As plântulas tiveram a raiz e o ápice meristemático removidos, sendo em seguida transferidas para meio MS contendo metade da concentração original de macronutrientes proposta por Murashige \& Skoog (1962), suplementado com $1 \mathrm{mgL}^{-1}$ da vitamina Barrueto e Cid (Anexo), contendo $2 \%$ de sacarose, 0,6\% de Agar (Merck) e 12 uM de 6benzilaminopurina (BAP). $\mathrm{O} \mathrm{pH}$ foi ajustado para 5,8 . Os explantes foram mantidos em sala de cultura de tecidos sob 16 horas de luz $\left(30 \mu \mathrm{E} \cdot \mathrm{m}^{-2} \cdot \mathrm{s}^{-1}\right)$ e 8 horas de escuro a uma temperatura de $26 \pm 2^{\circ} \mathrm{C}$.

\subsection{Cultura bacteriana}

Nos experimentos de transformação utilizou-se a linhagem de Agrobacterium tumefaciens, LBA 4404 com o vetor binário pTOK 233, gentilmente cedida pelo Dr. Antônio Figueira, do Centro de Energia Nuclear na Agricultura (CENA/USP). O T-DNA dessa linhagem contêm o gene repórter uidA, interrompido por uma seqüência INTRON (GUS-INTRON), o gene marcador $h p t$, da higromicina fosfotransferase ambos sob o controle do promotor $35 \mathrm{~S}$ do CaMV e o gene marcador nptll, da neomicina fosfotransferase 0 
qual esta sob o controle do promotor NOS da nopalina sintetase (Figura: 1).

O gene uidA expressa a proteína B-glucuronidase que em presença do substrato 5-bromo-4-cloro-3-indolil-ß-D-glucuronídeo (X-Gluc) realiza a dimerização oxidativa do mesmo, formando um precipitado insolúvel de cor azul (Jefferson et al., 1987). O gene, nptll confere resistência aos antibióticos do grupo dos aminoglicosilados, enquanto que 0 gene $h p t$ resistência à higromicina.

$A$ bactéria foi inoculada em meio $A B$ líquido (Anexo) suplementado com $50 \mathrm{mgL}^{-1}$ de canamicina e $100 \mathrm{mgL}^{-1}$ de higromicina sob agitação permanente em um agitador orbital a 200 $\mathrm{rpm}$ a $28^{\circ} \mathrm{C}$ de temperatura até atingir uma densidade ótica de $O \cdot D_{620 n m}=0,8$. Foi em seguida, sedimentada por centrifugação a $4732 \mathrm{~g}$ e $4^{\circ} \mathrm{C}$ por 10 minutos. A solução foi removida e o pellet bacteriano foi então ressuspêndido em meio MS líquido no mesmo volume que a bactéria foi cultivada, acrescido de 100 ì M de acetoseringona. 


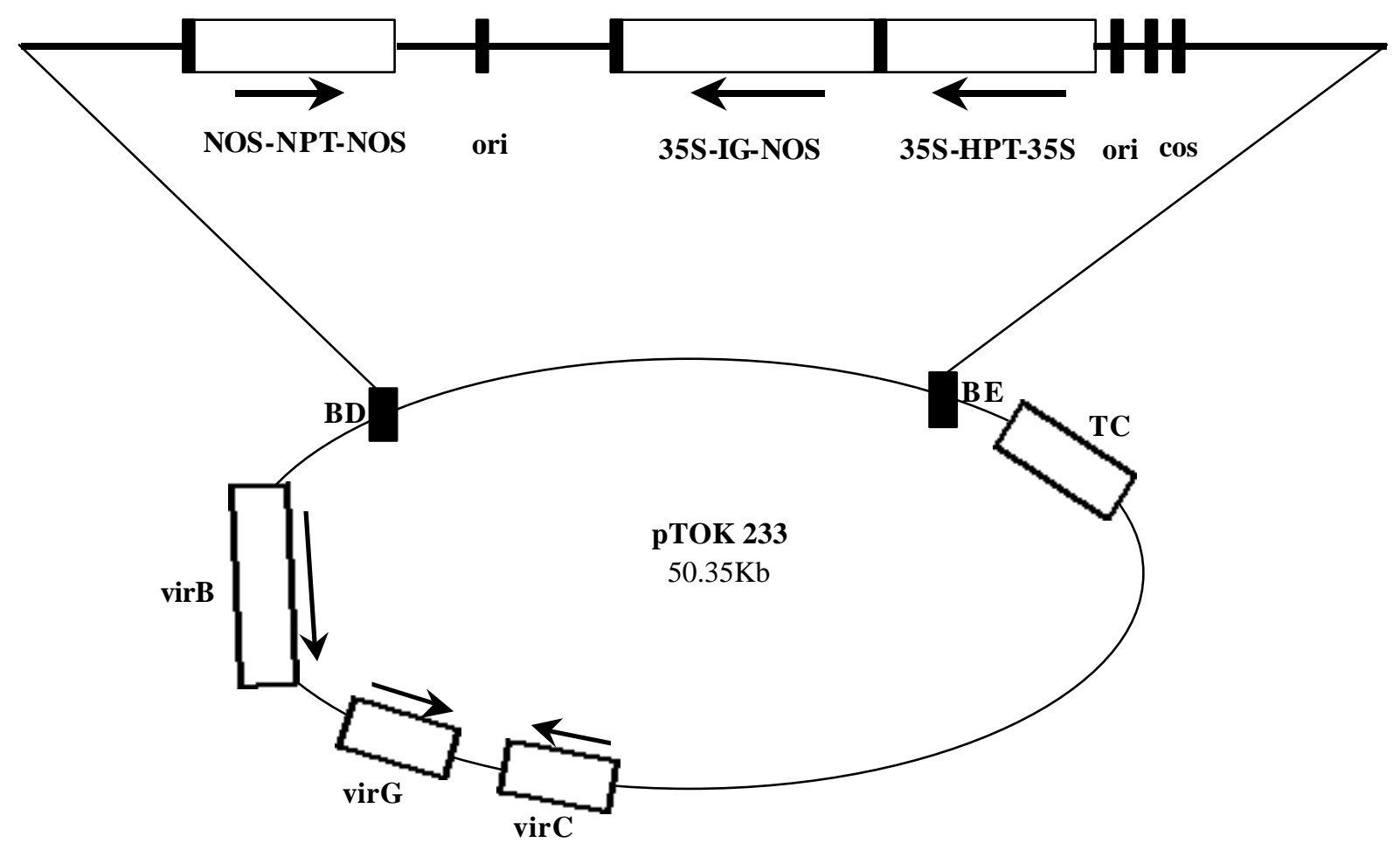

FIGURA 1 - Mapa do vetor binário pTOK233 (Ishida et al., 1996) contendo o inserto dos genes quiméricos uidA (35S-IG-NOS), hpt (35S-HPT-35S) e nptll (NOS-NPT-NOS). Borda direita: BD, Borda esquerda: BE, virB, virG e virC: Genes de virulência; ori: origem; cos: cosmídio

\subsection{Avaliação da expressão transitória do gene uidA}

Os experimentos de transformação foram avaliados através da expressão do gene uidA, pela detecção histoquímica da atividade da enzima B-glucuronidase, descrito por Jefferson et al. (1987). Os explantes foram colocados em frascos de $5 \mathrm{~mL}$ e 
cobertos com o substrato X-GLUC (ácido 5-bromo-4-cloro-3-indolilB-D-glucurônico). Após 16 horas a $37^{\circ} \mathrm{C}$, o reagente foi removido e as amostras foram lavadas três vezes com etanol $70 \%(\mathrm{v} / \mathrm{v})$ para remoção de pigmentos vegetais, como clorofila, permitindo uma melhor visualização dos pontos de coloração azul.

Com a remoção da clorofila os explantes foram mantidos em etanol $70 \%$, para posteriormente serem analisados $œ m$ uma lupa binocular $(40 \mathrm{X})$. Para realizar a comparação dos diferentes tratamentos, os pontos azuis de cada placa foram contados. Cada ponto azul independentemente do tamanho, foi considerado como ponto de expressão do gene uid-A, positivo para a atividade da âglucuronidase (GUS +).

\subsection{Transformação por biobalística}

O acelerador de partículas utilizado para realizar o bombardeamento foi o PDS1000/He ${ }^{\mathrm{TM}}$ (BioRad) descrito por Sanford et al. (1991). Emprega gás hélio àalta pressão para gerar a onda de choque que acelera as micropartículas.

Para otimizar as condições dos experimentos de transformação de Eucalyptus foram realizados vários testes preliminares de acordo com Sanford et al. (1993). Vários paramentos físicos tais como: pressão de hélio, distância de vôo das micropartículas foram avaliados. 
As micropartículas utilizadas nos experimentos de bombardeamento foram as de tungstênio M10 (GTE Sylvania Chemicals / Metals). O preparo das mesmas baseou-se no sistema desenvolvido no Laboratório de Biobalística do CENARGEN-EMBRAPA (Aragão et al., 1996).

O bombardeamento com micropartículas foi utilizado como método auxiliar para causar macro e microferimentos nos tecidos com o objetivo de aumentar a eficiência da transformação via Agrobacterium. Esta técnica de transformação conhecida como Agrobiobalística (Bidney et al., 1992; Brasileiro et al., 1996), é descrita como uma alternativa para melhorar a freqüência de transformantes, uma vez que os microferimentos não prejudicam a célula vegetal e são suficientes para induzir o processo de transferência do T-DNA.

O bombardeamento foi realizado em explantes de 21 dias com acúmulo de gemas axilares, obtidos conforme item: 3.2. Previamente os explantes tiveram suas folhas removidas e foram posicionados em placas de petri (18-20 por placa) contendo meio MS suplementado com 0,2 $\mathrm{mgL}^{-1}$ de BAP, 0,01 $\mathrm{mgL}^{-1}$ de ANA, 1 $\mathrm{mgL}^{-1}$ de vitamina MM (Anexo), $2 \%$ (v/v) de sacarose e 0,8\% (v/v) de Phytagel (Sigma). Os explantes foram dispostos em círculo, a uma distância de $15 \mathrm{~mm}$ do centro da placa, com a região de acúmulo de gemas direcionada para cima. 


\subsection{Estabilidade e expressão da atividade da B-glucuronidase}

A estabilidade da expressão do gene uid- $A$ foi analisada em explantes de 21 dias com acúmulo de gemas bombardeados e inoculados com a bactéria. A pressão de disparo utilizada foi de 650 PSI, a uma distância de $9,5 \mathrm{~cm}$ do alvo. Os experimentos foram avaliados ao longo do tempo (5, 10, 15 dias), verificando-se a expressão do gene uidA pelo teste histoquímico da atividade da âglucuronidase, considerando o número de pontos azuis por tratamento. Foram realizadas três repetições, contendo 18 a 20 explantes por placa.

\subsection{Distância do alvo}

Para avaliar a melhor distância entre a câmara de pressão e o tecido alvo, explantes com acúmulo de gemas axilares foram bombardeados com uma pressão de disparo de 650 PSI, seguida pela inoculação com a bactéria, sendo co-cultivada a $26 \pm 2^{\circ} \mathrm{C}$, em ausência de luz por 48 horas. As distâncias usadas foram: 3,5; 6,5, 9,5 e $12,5 \mathrm{~cm}$. A avaliação foi realizada 10 dias após a inoculação, através do teste de detecção histoquímica da atividade da âglucuronidase, considerando o número de pontos azuis por tratamento. Foram realizadas três repetições, contendo 18 a 20 explantes por placa. 


\subsection{Pressão de disparo}

Para avaliar a melhor pressão de disparo, explantes de 21 dias com acumulo de gemas axilares foram bombardeados avaliando quatro diferentes pressões de disparo: 650, 900, $1100 \mathrm{e}$ $1350 \mathrm{PSI}$, seguidos pela inoculação com a bactéria, sendo cocultivados em uma temperatura de $26 \pm 2^{\circ}$ C. Após 48 horas na ausência de luz, os explantes foram transferidos para a luz. A distância usada durante o bombardeamento foi de $9,5 \mathrm{~cm}$. Os experimentos foram avaliados 10 dias após a inoculação, pelo teste histoquímico da atividade da â-glucuronidase, considerando o número de pontos azuis por tratamento. Foram realizadas três repetições, contendo 18 a 20 explantes por placa.

\subsection{Temperatura de co-cultivo}

Para verificar qual seria a melhor temperatura de co-cultivo a ser utilizada nos experimentos, explantes com acúmulo de gemas axilares foram bombardeados e inoculados com a bactéria, e submetidos a diferentes temperaturas, co-cultivados em ausência de luz, por 48 horas em uma incubadora tipo BOD. As temperaturas avaliadas foram: 22,26 e $28^{\circ} \mathrm{C}$. O bombardeamento foi realizado a uma distância de $9,5 \mathrm{~cm}$ do alvo, com uma pressão de 650 PSI. A avaliação foi realizada 10 dias após a inoculação, pelo teste histoquímico da atividade da â-glucuronidase, considerando-se o 
número de pontos azuis por tratamento. Foram realizadas quatro repetições, contendo 18 a 20 explantes por placa.

\subsection{Caracterização anatômica do explante}

Um estudo anatômico de explantes com e sem acumulo de gemas axilares foi realizado para auxiliar no processo de infecção e transformação de explantes com acumulo de gemas axilares. O material vegetal foi fixado em solução de Karnovsky (Karnovsky, 1965), desidratado em uma série alcoólica-etílica de 70, 80, 90 e $100 \%$ (v/v) por 10 minutos em cada concentração, sendo em seguida infiltrado em historesina glicol metacrilato (Reichert- Jung).

Para as análises morfológicas gerais das células, as amostras foram seccionadas em micrótomo (RM2045, Leica) em secções de $5 \mu \mathrm{M}$ de espessura, coradas com a solução contendo $0,05 \%$ de azul de toluidina em $0,15 \mathrm{M}$ de $\mathrm{K}_{2} \mathrm{PO}_{4}$ (Sakai, 1973) e montadas em Entelan (Merck).

\subsection{Localização da região de expressão do gene uidA}

A análise histológica do material inoculado com Agrobacterium foi realizada para identificar quais eram os tecidos que expressavam o gene uidA. Explantes com acúmulo de gemas axilares de 21 dias, obtidos conforme item 3.2, foram transferidos 
para frascos tipo Majenta contendo $30 \mathrm{~mL}$ de meio de alongamento líquido e sonicados por 60 segundos. Após a sonicação, os explantes foram inoculados com a bactéria $\left(O D_{620 \mathrm{~nm}}=0,8\right) \mathrm{e}$ mantidos por 24 horas a 26ํㅡ C, sob agitação de 80 rpm. Posteriormente foram transferidos para meio de alongamento, contendo 0,6\% (v/v) de Agar (Merck), onde foram co-cultivados no escuro por 48 horas a 26ำ C. Três dias após a inoculação o material foi submetido ao ensaio histoquímico da atividade da â glucuronidase. Os explantes que apresentaram expressão do gene uid $A$ foram fixados em solução de Karnovsky, desidratados em série alcoólica etílica de 70, 80, 90 e $100 \%$ (v/v) por 10 minutos em cada concentração, sendo em seguida infiltradas em historesina glicol metacrilato (Reichert-Jung).

Para as análises morfológicas gerais das células, as amostras foram seccionadas em micrótomo (RM2045, Leica), em secções de $5 \mu \mathrm{M}$ de espessura, coradas com a solução contendo $0,05 \%$ de azul de toluidina em 0,15 M de $\mathrm{K}_{2} \mathrm{PO}_{4}$ (Sakai, 1975) e montadas em Entelan (Merck).

Metade das lâminas, não foram coradas, para servirem de controle da visualização das regiões que expressaram o gene uidA, uma vez que a coloração dos cortes com azul de toluidina, compromete a detecção das regiões de coloração azulada referente a atividade da â-glucuronidase. 


\subsection{Susceptibilidade de espécies de Eucalyptus a agentes seletivos.}

Neste experimento avaliou-se a susceptibilidade de espécies de Eucalyptus a dois antibióticos do grupo dos aminoglicosilados; geneticina $\left(10 \mathrm{mgL}^{-1}\right)$ e canamicina $\left(100 \mathrm{mgL}^{-1}\right)$. Sementes de E. robusta, E. dunni, E. urophylla, E. pellita, E. brassiana, E. saligna, E. grandis e do híbrido (E. grandis $X$ E. urophylla) foram desinfectadas, conforme descrito no item $3.1 \mathrm{e}$ transferidas para meio MS com $2 \%(\mathrm{v} / \mathrm{v})$ de sacarose, 0,6 \% (v/v) de Agar (Merck) e pH 5,8 acrescido ou não de antibiótico. Para cada experimento avaliou-se três repetições por tratamento com 40 sementes por placa. As avaliações foram realizadas 60 dias após a germinação considerando-se a porcentagem total de plantas vivas por placa.

\subsection{Susceptibilidade de diferentes progênies de Eucalyptus a agentes seletivos.}

Neste experimento foi avaliada a susceptibilidade de sete progênies de Eucalyptus grandis a dois antibióticos do grupo dos aminoglicosilados; geneticina (10 $\left.\mathrm{mgL}^{-1}\right)$ e canamicina (100 $\mathrm{mgL}^{-1}$ ). As sementes foram desinfectadas, conforme descrito no item $3.1 \mathrm{e}$ transferidas para meio MS com $2 \%(\mathrm{v} / \mathrm{v})$ de sacarose, 0,6 \% (v/v) de Agar (Merck) e pH 5,8 acrescido ou não de antibiótico. Para cada 
experimento avaliaram-se três repetições por tratamento com 40 sementes por placa. As avaliações foram realizadas ao longo do tempo; 14, 21, 35, 50 e 60 dias após a germinação considerando-se a porcentagem total de plantas vivas.

\subsection{Seleção de clones com alta taxa de regeneração e alta susceptibilidade a agentes seletivos}

O experimento teve como objetivo selecionar clones que apresentam alta taxa de regeneração e susceptibilidade a antibióticos do grupo dos aminoglicosilados. Avaliaram-se 10 clones, quanto à sua capacidade de regeneração de plantas a partir de folhas e sua susceptibilidade àcanamicina $\left(50 \mathrm{mgL}^{-1}\right)$, geneticina (5 $\left.\mathrm{mgL}^{-1}\right)$ e a combinação de ambos, canamicina $\left(25 \mathrm{mgL}^{-1}\right) \mathrm{e}$ geneticina $\left(5 \mathrm{mgL}^{-1}\right)$. Foram realizadas três repetições por tratamento com 40 explantes por placa.

Folhas provenientes dos clones, foram cortadas e transferidas para meio MS sólido suplementado com $0,5 \mathrm{mgL}^{-1}$ de TDZ onde permaneceram no escuro por 30 dias antes de serem transferidas para a luz. As avaliações foram realizadas 30 dias após a transferência das plantas para a luz. 


\subsection{Seleção de clones susceptíveis àtransformação}

Neste experimento foram avaliados 3 clones quanto à susceptibilidade à transformação por Agrobacterium. Esses clones foram escolhidos por apresentarem taxa de regeneração superior a $70 \%$ e alta susceptibilidade aos antibióticos canamicina e geneticina pertencentes ao grupo dos aminoglicosilados. Os explantes foram imersos em $30 \mathrm{~mL}$ de meio MS líquido, em frascos Majenta e sonicados por trinta segundos. Após a sonicação, os explantes foram inoculados com a bactéria $\left(\mathrm{OD}_{620 \mathrm{~nm}}=0,8\right)$ e mantidos por 24 horas a $26^{\circ} \mathrm{C}$, sob agitação de $80 \mathrm{rpm}$. Posteriormente, foram transferidos para meio de alongamento $(\mathrm{AL})$ sólido e co-cultivados no escuro por 48 horas a 26ํㅡㄴ $\mathrm{C}$. Sete dias após a inoculação os explantes foram submetidos ao ensaio histoquímico de atividade da B-glucuronidase considerando-se o número de folhas com pontos azuis por tratamento. Foram realizadas três repetições, contendo 15 plântulas/placa.

\subsection{Aparelho de sonicação}

O aparelho usado nos experimentos de sonicação foi 0 ULTRA-SOM (Thornton-INPEC Eletrônica LTDA) modelo G/T, tipo $\mathrm{T} 7$, com $40 \mathrm{KHz}$ de freqüência fixa e potência de $30 \mathrm{~W}$. 


\subsection{Efeito do tempo de sonicação}

Nesse experimento o objetivo foi avaliar o efeito do tempo de sonicação dos explantes na eficiência de transformação por Agrobacterium. Plântulas com 15 dias, do clone 6, foram transferidas para frascos tipo Majenta contendo $30 \mathrm{~mL}$ de meio de alongamento líquido e sonicadas. Diferentes tempos de sonicação foram avaliados: 0, 30, 60, 90 e 120 segundos. Após o tratamento os explantes foram inoculados com a bactéria $\left(O . D_{620 \mathrm{~nm}}=0,8\right)$ e mantidos por 24 horas a $26^{\circ} \mathrm{C}$, sob agitação de $80 \mathrm{rpm}$. Posteriormente foram transferidos para meio de alongamento ( $A L$ ) sólido, sendo mantidos sob co-cultivo no escuro por 48 horas a $26^{\circ} \mathrm{C}$. Sete dias após a inoculação, os explantes foram submetidos ao ensaio histoquímico para determinação da expressão da ßglucuronidase, onde avaliou-se 0 número de plantas que apresentaram pontos azuis por tratamento. Foram realizadas quatro repetições, contendo 15 plântulas/placa.

\subsection{Efeito da pós-sonicação}

O experimento teve como objetivo avaliar o efeito da póssonicação na eficiência de transformação por Agrobacterium. Plântulas com 15 dias do clone 6 foram transferidas para Majentas contendo $30 \mathrm{~mL}$ de meio de alongamento líquido, sonicadas por 60 segundos e inoculadas com a bactéria $\left(O \cdot D_{620 \mathrm{~nm}}=0,8\right)$. Após a 
inoculação as plântulas foram novamente sonicadas com diferentes períodos de tempo: 0, 10, 30, 60 e 90 segundos. Os explantes foram então mantidos em contato com a bactéria por 24 horas a 26 C, sob agitação de $80 \mathrm{rpm}$. Posteriormente os explantes foram transferidos para meio de alongamento $(\mathrm{AL})$ sólido onde permaneceram em cocultivo, no escuro por 48 horas a 26으 C. Sete dias após a inoculação os explantes foram submetidos ao ensaio histoquímico para determinação da expressão da ß-glucuronidase, onde avaliouse o número de plantas que apresentaram pontos azuis por tratamento. Foram realizadas quatro repetições, contendo 15 plântulas por repetição.

\subsection{Análise dos dados}

Todos os dados foram expressos na forma de média e desvio padrão. As análises dos experimentos foram feitas pelo Teste de Tukey, o delineamento experimental foi totalmente casualizado. 


\section{RESULTADOS E DISCUSSÃO}

\subsection{Determinação da estabilidade da expressão do gene uidA}

$\mathrm{Na}$ literatura existe uma série de relatos sobre taxas da conversão de expressão transitória para expressão estável. Finer \& McMullen (1990) observaram uma conversão menor de $1 \%$ enquanto que Klein et al. (1988) observaram $5 \%$ de expressão estável.

Este experimento teve como objetivo conhecer 0 comportamento da atividade da B-glucuronidase ao longo do tempo em explantes com acumulo de gemas axilares, submetidos a agrobiobalística. No experimento observou-se que ao longo do tempo, após a inoculação com Agrobacterium ocorre uma redução da porcentagem dos explantes que apresentam atividade da Bglucuronidase, com uma redução de $52 \%$ nos primeiros 5 dias para 8,6 \% após 15 dias. Na Figura 2 podemos observar a transitoriedade do material apresentando uma considerável redução da atividade da B-glucuronidase nos primeiros 15 dias após a inoculação com a bactéria. Entretanto após 15 dias observa-se uma maior estabilidade da atividade da B-glucuronidase. 
Os resultados demonstram que nos experimentos de transformação utilizando o gene uidA há uma grande redução no número de explantes que apresentam atividade GUS, existindo a necessidade de trabalhar-se com um grande número de explantes para obter-se sucesso na obtenção de plantas transgênicas.

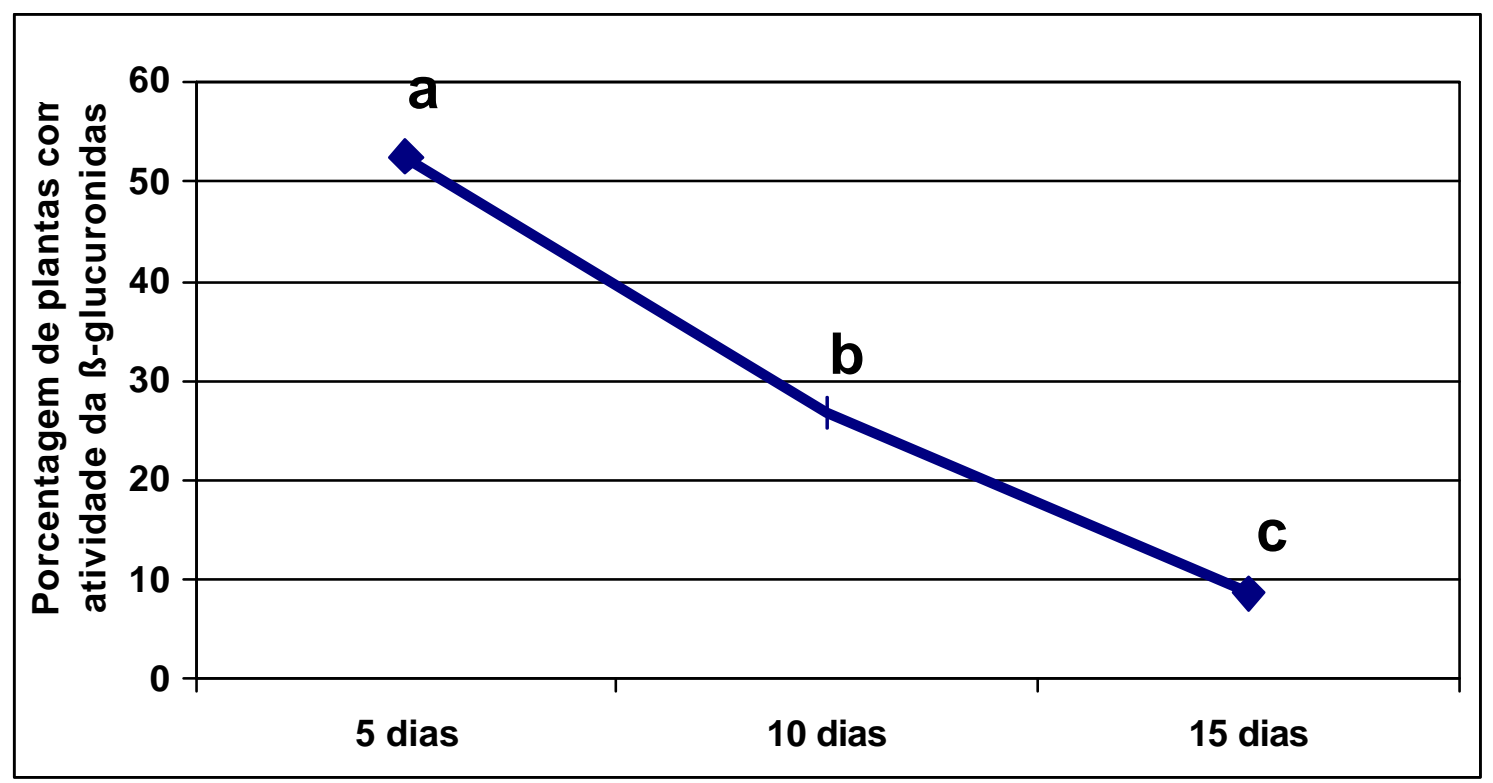

Figura 2 - Estabilidade da expressão do gene uidA (GUS) ao longo do tempo. Médias com a mesma letra não diferem estatisticamente ao nível de $1 \%$ pelo Teste de Tukey. Explantes com acúmulo de gemas axilares bombardeados com uma pressão de disparo de $650 \mathrm{PSI}$, a uma distância de $9,5 \mathrm{~cm}$ do alvo. 


\subsection{Determinação da melhor distância do alvo para o bombardeamento}

A maior porcentagem de plantas com expressão do gene uidA foi observada nos experimentos de bombardeamento dos explantes quando a distância entre a membrana carreadora e o tecido alvo foi de $9,5 \mathrm{~cm}$. A Figura 3, demonstra que não há diferença significativa entre as distâncias de bombardeamento de $12,5 \mathrm{~cm}$ e $9,5 \mathrm{~cm}$. O que observamos pela figura é que quando $o$ tecido alvo está muito próximo $(3,5 \mathrm{~cm})$ da membrana carreadora ocorre oxidação e morte dos explantes. Não foi observada diferença significativa do material não bombardeado com o bombardeado a pequenas distâncias (Figura 3).

Resultados semelhantes foram demonstrados por Klein et al. (1988) e Russell et al. (1992), os quais observaram que ocorre um maior dano æ̀s células quando estas estão muito próximas da fonte de partículas. Segundo Sanford et al. (1993) as menores distâncias provocam maiores acelerações, desta forma podem danificar o tecido comprometendo a sua regeneração ou mesmo causando morte. 


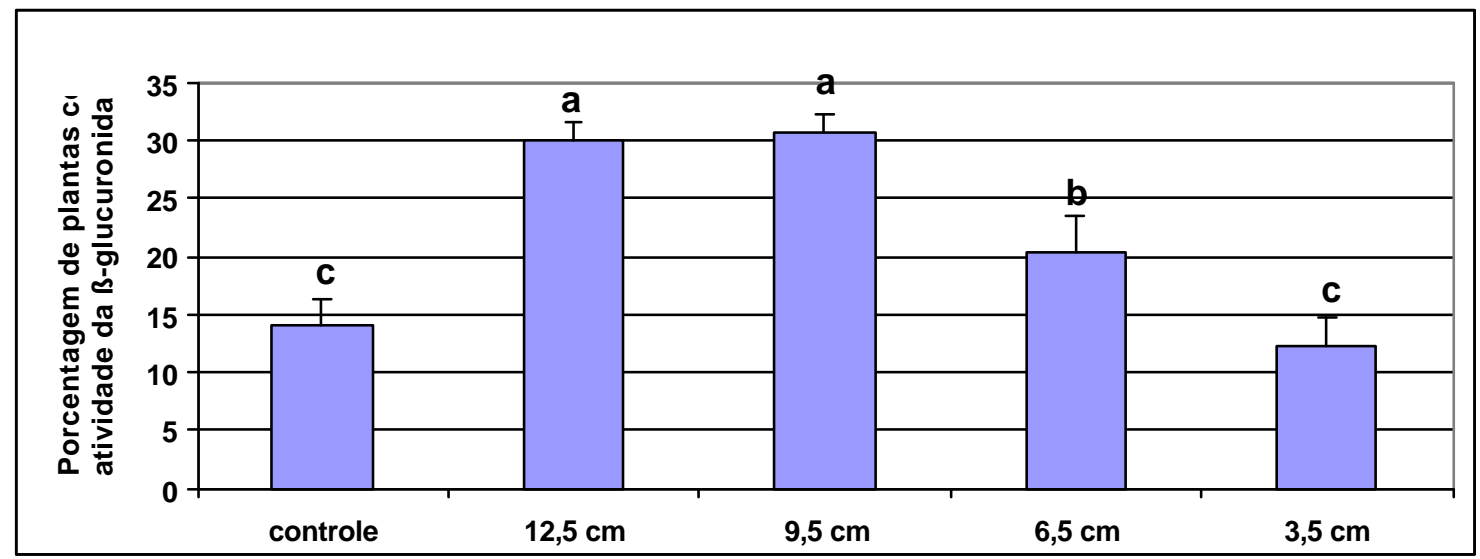

Figura 3 - Avaliação de diferentes distâncias entre a membrana carreadora e o tecido alvo. Explantes com acúmulo de gemas axilares bombardeados com uma pressão de disparo de 650 PSI. A avaliação foi realizada 10 dias após a inoculação. Médias com a mesma letra não diferem significativamente ao nível de $5 \%$ pelo Teste de Tukey. As barras verticais indicam o desvio padrão da média.

\subsection{Bombardeamento com diferentes pressões de disparo}

$\mathrm{Na}$ Figura 4, observa-se que quanto maior a pressão utilizada no bombardeamento maior o número de plantas que apresentam pontos de coloração azul, referente à atividade da Bglucuronidase. As pressões de disparo superiores a 1000 PSI foram as que apresentaram os melhores resultados. A maior porcentagem de explantes com atividade da B-glucuronidase foi obtida empregando a pressão de 1350 PSI, entretanto não há diferença significativa entre as pressões de 1350 e 1100 PSI. A distância entre 
a câmara de pressão e o alvo, utilizada durante o bombardeamento, foi a de 9,5 cm, escolhida com base nos resultados do experimento anterior.

Sanford et al. (1993) também relataram que pressões de gás Hélio próximas a 1000 PSI são ótimas ou quase ótimas para a maioria das aplicações, segundo esses autores, pressões menores não provocam aceleração suficiente para que as micropartículas penetrem nas células e pressões maiores causam danos irrecuperáveis no tecido a ser transformado.

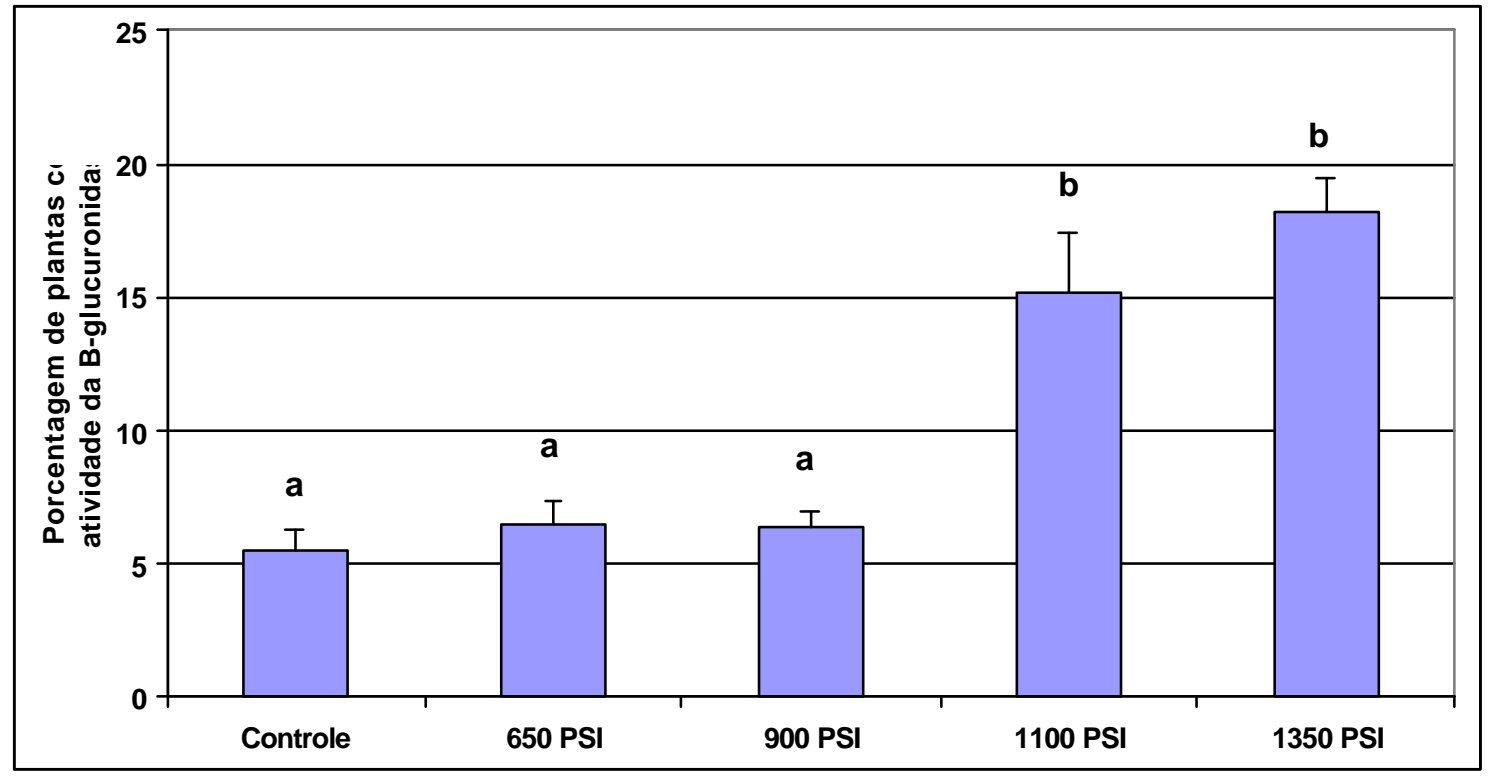

Figura 4 - Avaliação de pressões de disparo. Explantes com acúmulo de gemas axilares submetidos a diferentes pressões de disparo a uma distância de $9,5 \mathrm{~cm}$ do alvo. Avaliações realizadas 15 dias após a inoculação. Médias com a mesma letra não diferem significativamente ao nível de $1 \%$ pelo Teste de Tukey. Barras verticais indicam o desvio padrão da média. 


\subsection{Temperatura de co-cultivo}

A temperatura de $26^{\circ} \mathrm{C}$ durante $\mathrm{o}$ co-cultivo foi a que apresentou a maior porcentagem de explantes com atividade da Bglucuronidase. Pela figura 5 , observamos que há uma grande redução do número de explantes que apresentam atividade da Bglucuronidase quando a temperatura de co-cultivo é elevada para $28^{\circ}$ C. Entretanto, não há diferença significativa entre as temperaturas de $22^{\circ} \mathrm{C}$ e $28^{\circ} \mathrm{C}$.

Na literatura sobre transformação via Agrobacterium (Dillen et al., 1997) há uma grande variação nas temperaturas de co-cultivo utilizadas. Riker, em 1926 observou que a formação de tumores é dependente da temperatura, a correlação da termo sensibilidade na formação da galha reflete a dependência da transferência do T-DNA da bactéria para as plantas, que é sensível àtemperatura.

Fullner \& Nester (1996) demonstraram que a mobilização do plasmídio IncQ via "maquinaria" vir da Agrobacterium é altamente dependente da temperatura. $O$ mecanismo de transferência do TDNA é afetado pela temperatura de co-cultivo utilizada no processo de infecção, este tipo de conjugação não esta ainda muito bem elucidado.

Dillen et al. (1997) utilizando dois sistemas de transformação, com três tipos de plasmídios distintos em duas espécies verificou uma relação direta entre o grau de infecção e a temperatura de co-cultivo. A expressão transitória da Bglucuronidase decresce e quando a temperatura aumentou de $22^{\circ}$ 
C para 25ำ C, e não chegou a ser detectada a 29ํ․ Cstes dados demonstram a importância de se determinar anteriormente qual a temperatura ideal para otimização do processo de infecção durante o co-cultivo.

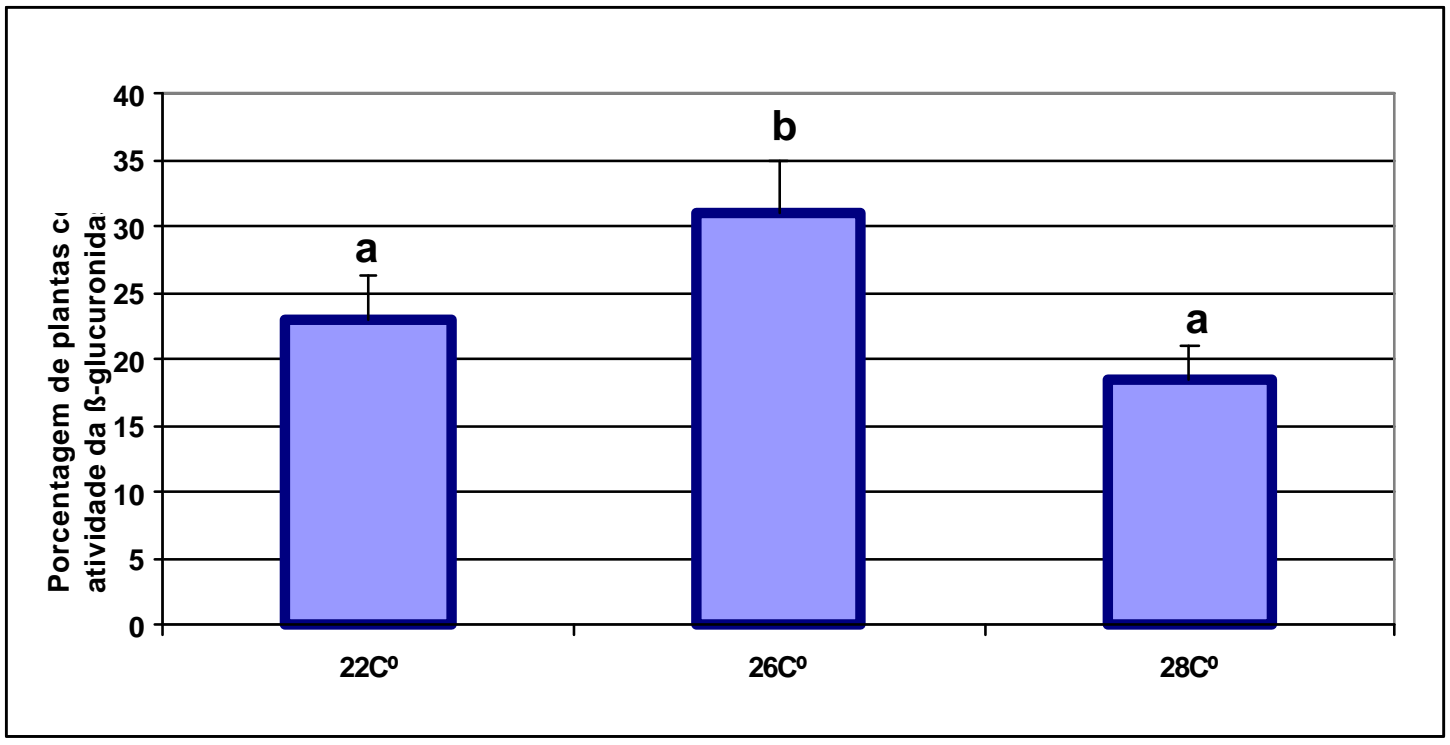

Figura 5 - Efeito da temperatura de co-cultivo no processo de infecção. Explantes com acúmulo de gemas axilares bombardeados com uma pressão de disparo de $650 \mathrm{PSI}$, a uma distância de $9,5 \mathrm{~cm}$ do tecido alvo. A avaliação foi realizada 10 dias após a inoculação. Médias com a mesma letra não diferem significativamente ao nível de $5 \%$ pelo Teste de Tukey. As barras verticais indicam o desvio padrão da média. 


\subsection{Caracterização anatômica do explante e localização da região com expressão do gene uidA}

A importância do estudo histológico e anatômico esta em propiciar uma visão detalhada dos tecidos que irão regenerar, esta informação é de grande interesse, especialmente em sistemas de transferência de genes (Matsumoto et al., 1996). Conhecer a localização do tecido que se quer transformar pode contribuir para 0 sucesso da metodologia de transformação .

Mukhopadhyay et al. (1992) atribuíram a baixa eficiência do processo de transformação, ao fato da regeneração das plantas ocorrer a partir de células meristemáticas competentes, mas que por estarem localizadas muito além da superfície do explante, entre 450 - $625 \mu \mathrm{m}$, não são acessíveis à bactéria ou então, não são fisiologicamente competentes para a transformação.

Com base nestas observações, realizou-se um estudo anatômico e histológico para compreender como ocorre a formação do acúmulo de gemas axilares e conhecer a anatomia e localização do tecido alvo que se quer transformar, para com isso auxiliar no processo de transformação.

Na Figura 6, observamos que os explantes avaliados após

21 dias de cultivo em meio de cultura MS contendo metade da concentração de macronutrientes e suplementado com $12 \mu \mathrm{M}$ de BAP, apresentaram-se bastante alterados. Nesta fase, verifica-se um intumescimento das gemas axilares, na superfície da qual aparecem as primeiras áreas verdes que mais tarde darão origem 
às plântulas.

Com as análises histológicas realizadas nos explantes pôde-se visualizar como ocorre o processo de formação da região com acúmulo de gemas. Podemos constatar através da Figura 7 que os explantes apresentam uma região meristemática superficial, formada a partir da re-diferenciação de células da epiderme e do parênquima cortical.

O processo de formação dos meristemóides em explantes de eucalipto não é sincrônico; meristemóides de diferentes tamanhos e fases podem ser visualizados lado a lado, na mesma região, Figura 7.

As análises histológicas sugerem que no eucalipto, as gemas axilares desenvolvem-se a partir destes meristemóides. As gemas axilares, em desenvolvimento estabelecem uma conexão vascular com o tecido do explante. As análises histológicas conduzidas no estudo com eucalipto demonstram que as células dos meristemóides possuem as características de células competentes para a transformação genética via Agrobacterium, conforme a descrição feita por Sangwan et al. (1992); são células pequenas isodiamétricas com paredes delgadas, citoplasma denso e núcleo proeminente, estando localizadas na superfície do explante e assim, bastante acessíveis àinfecção pela bactéria.

Durante a realização dos experimentos de transformação dos explantes com acúmulo de gemas axilares, não observamos a presença de brotos originados das gemas axilares inteiramente transgênicos, indicando assim, que não são fisiologicamente 
competentes à transformação. De todos os experimentos com Agrobiobalística realizados em explantes com acumulo de gemas axilares, apenas pontos de coloração azulada, referente àatividade da B-glucuronidase nos primórdios foliares foram observados. Nos cortes transversais de explantes inoculados com Agrobacterium (Figura 8) a reação positiva da B-glucuronidase foi apenas observada nas células da epiderme e do parênquima cortical.

Entre as diferentes espécies de plantas, e mesmo dentro de uma mesma espécie há uma grande variabilidade no grau de susceptibilidade à Agrobacterium tumefaciens e Agrobacterium rhizogenes (Decleene \& Deley, 1976; Anderson \& Moore, 1979; Porter, 1991). Vários trabalhos demonstram que dentro de uma mesma planta existem diferentes níveis de susceptibilidade entre tecidos, órgãos e tipo de célula àinfecção por Agrobacterium.

Ritchie et al. (1993) observaram em secções de tecidos de milho, que a atividade da ß-glucuronidase estava presente apenas em células do cilindro vascular, tecido cotiledonar e em folhas, não sendo encontrada atividade no broto apical, apenas em segmentos do broto.

Resultados semelhantes também foram obtidos por Shen et al. (1993) os quais observaram expressão do gene uidA nas folhas e na região cotiledonar.

Schlappi \& Hohn (1992) trabalhando com embriões de 3 cultivares de milho, verificaram que em brotos apicais, o meristema apresentou competência àtransformação apenas quando começou a diferenciar-se. 
Dekathen \& Jacobsen (1995) demonstraram em Pisum sativum que apenas células diferenciadas, próximas ao sistema vascular de cotilédones e região do epicótilo, apresentam susceptibilidade àtransformação por Agrobacterium .

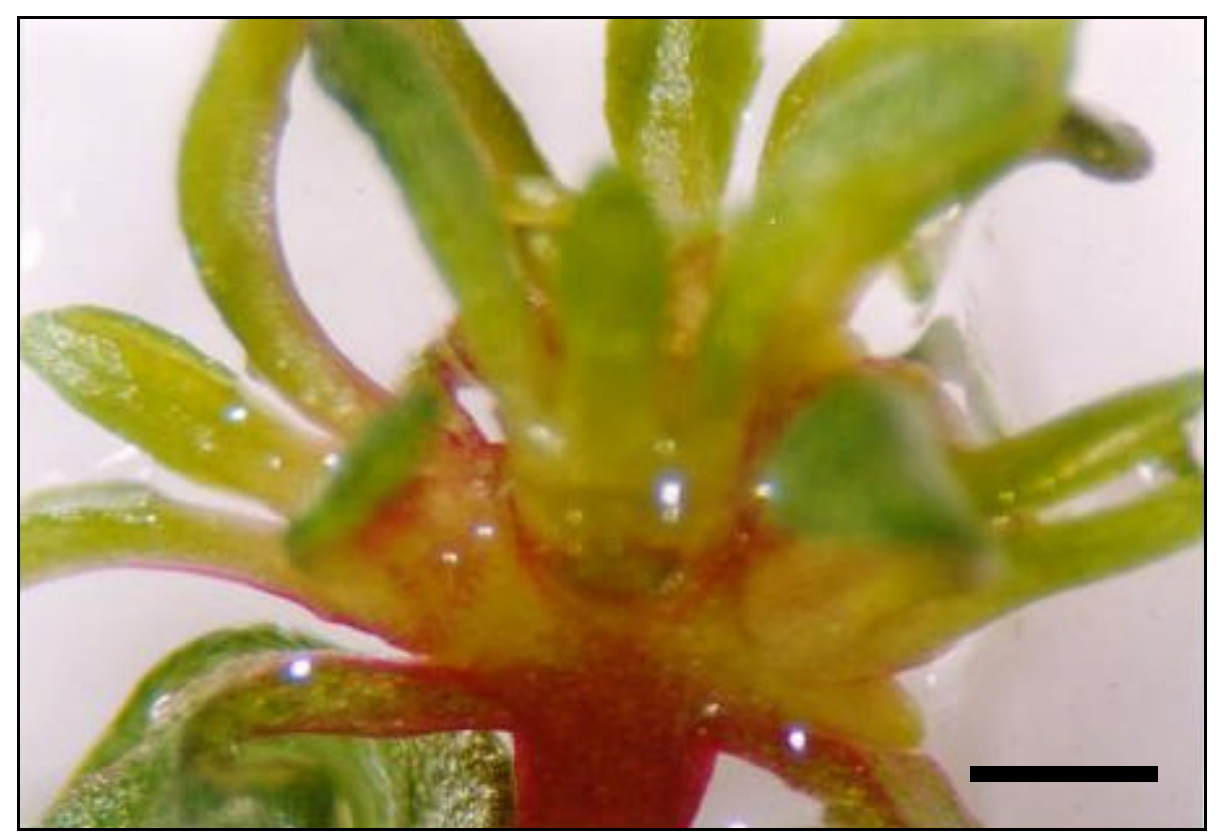

Figura 6 - Explante de Eucalyptus com acúmulo de gemas axilares (barra $=2 \mathrm{~mm}$ ). 

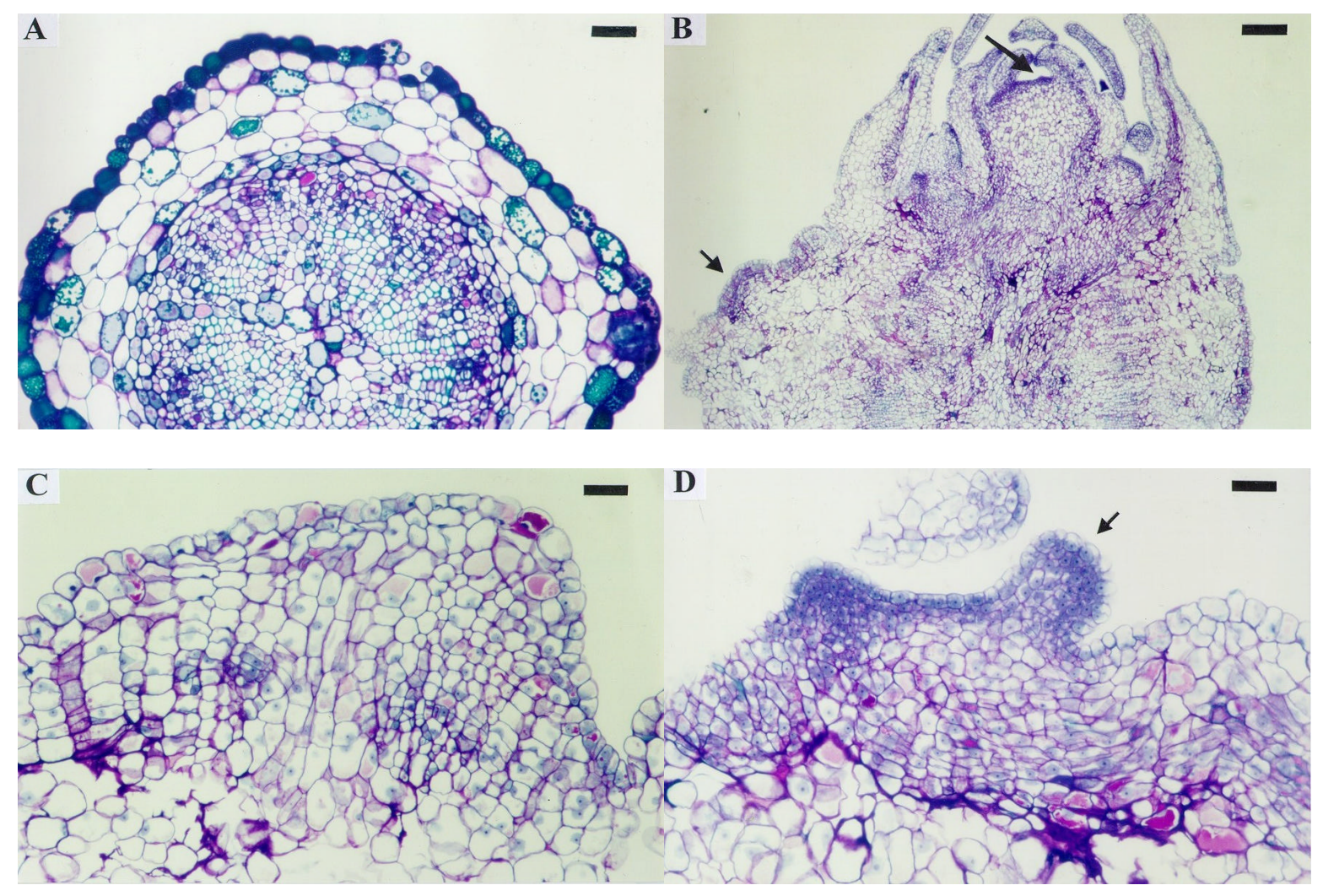

Figura 7 - Fotomicrográfias do material preparado em lâminas histológicas.

(A) Corte transversal do hipocótilo, sem a indução das gemas axilares (barra $=199 \mu \mathrm{m}$ ). $($ B) Corte transversal da região com acúmulo de gemas axilares, com a presença de gemas em diferentes fases de desenvolvimento, demonstrando que a formação

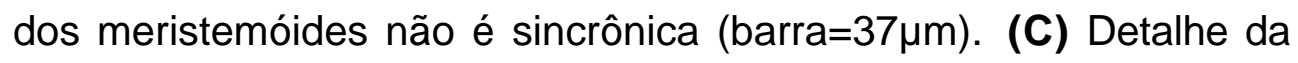
região de uma gema neo-formada (Detalhe Figura B; barra $=19 \mu \mathrm{m}$ ). (D) Região meristemática com início da formação das gemas axilares (barra $=19 \mu \mathrm{m})$. 


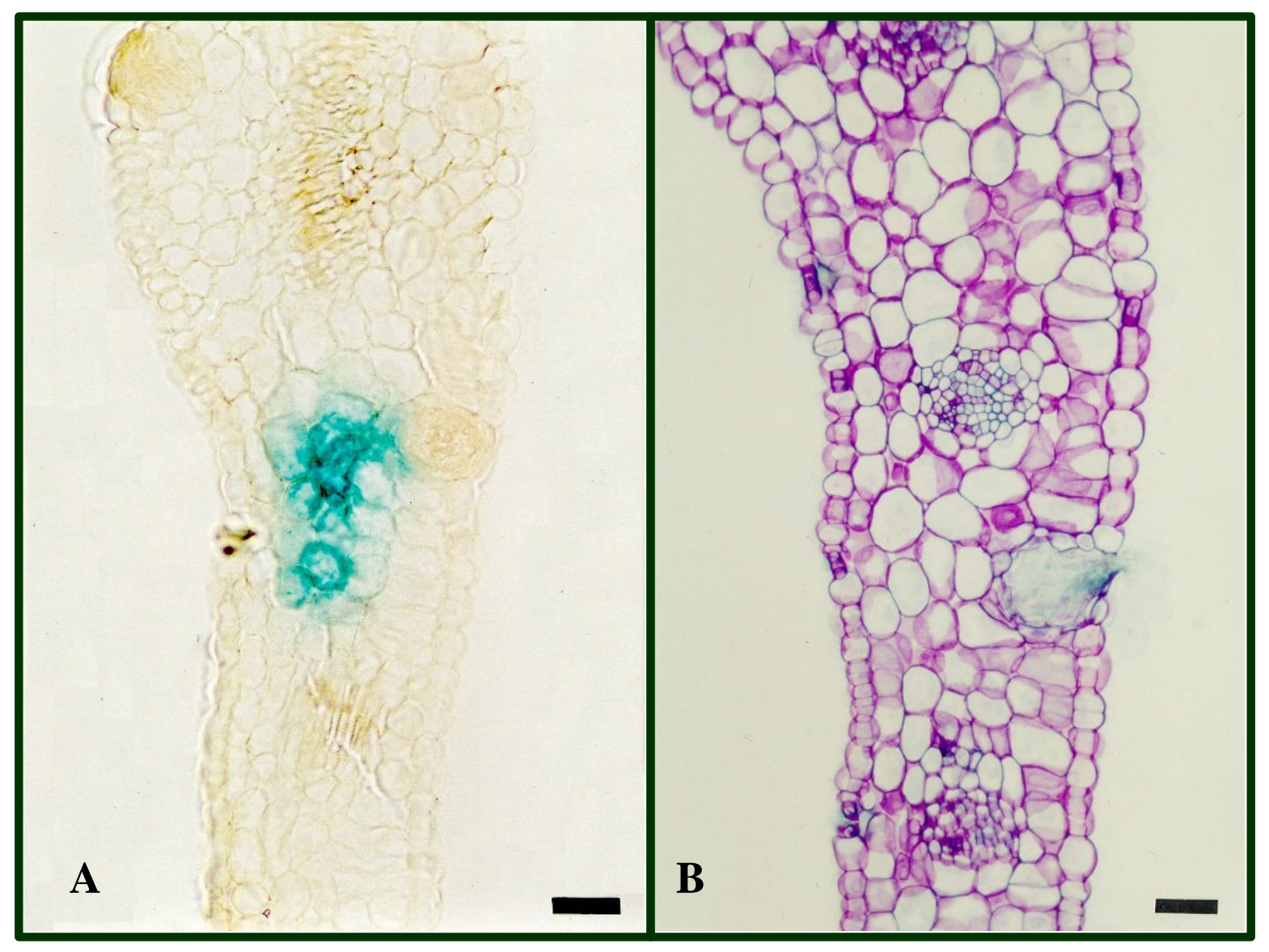

Figura 8 - Corte longitudinal de secções de primórdios foliares de explantes com acumulo de gemas axilares inoculados com Agrobacterium. (A)

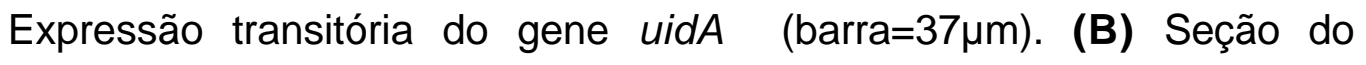
explante submetido a coloração com azul de toluidina (barra=37 $\mu \mathrm{m}$ ). 


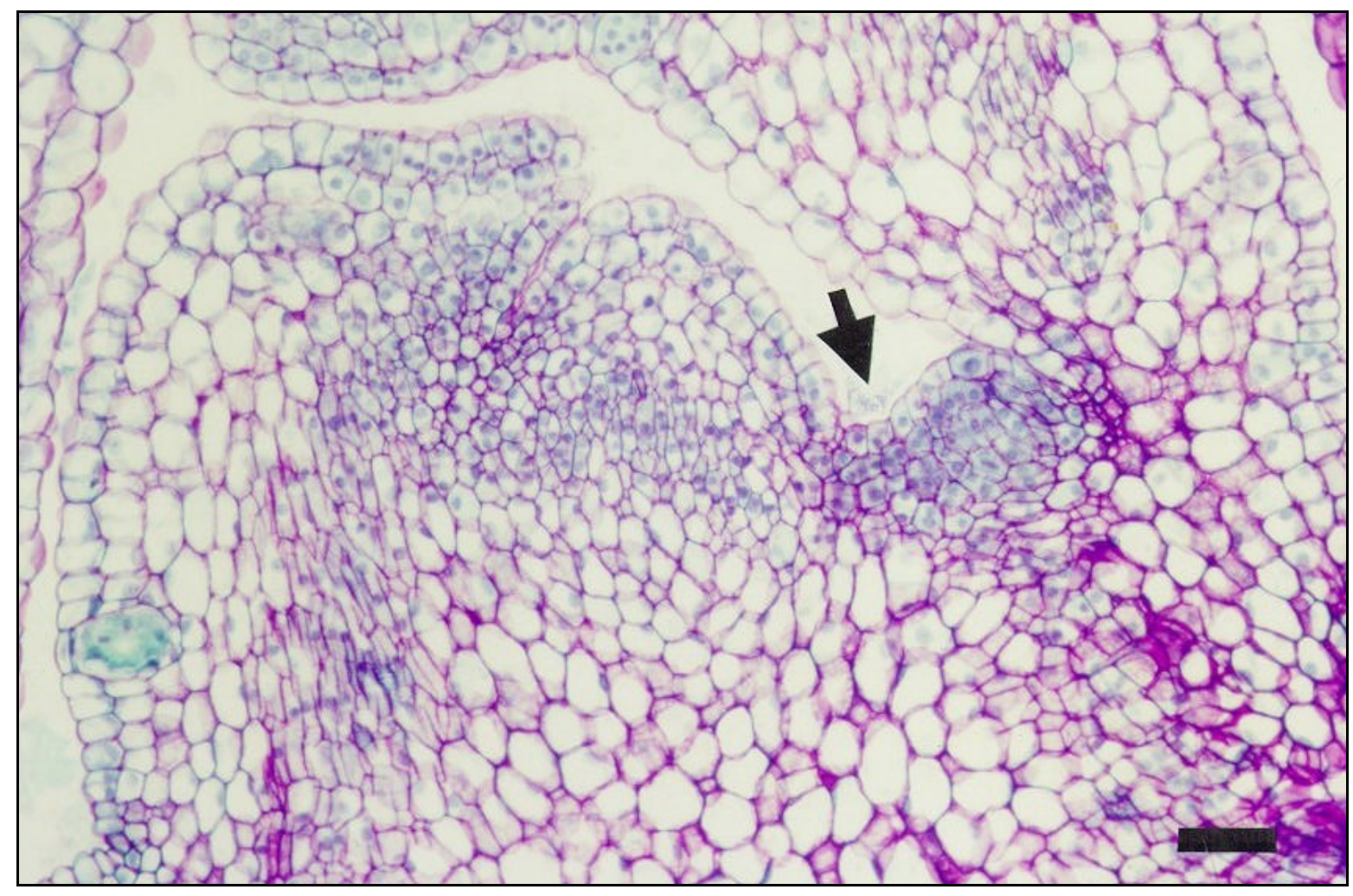

Figura 9 - Seção transversal da região com acúmulo de gemas axilares, inoculada com Agrobacterium. A seta indica a presença de Agrobacterium na

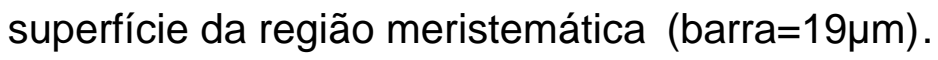




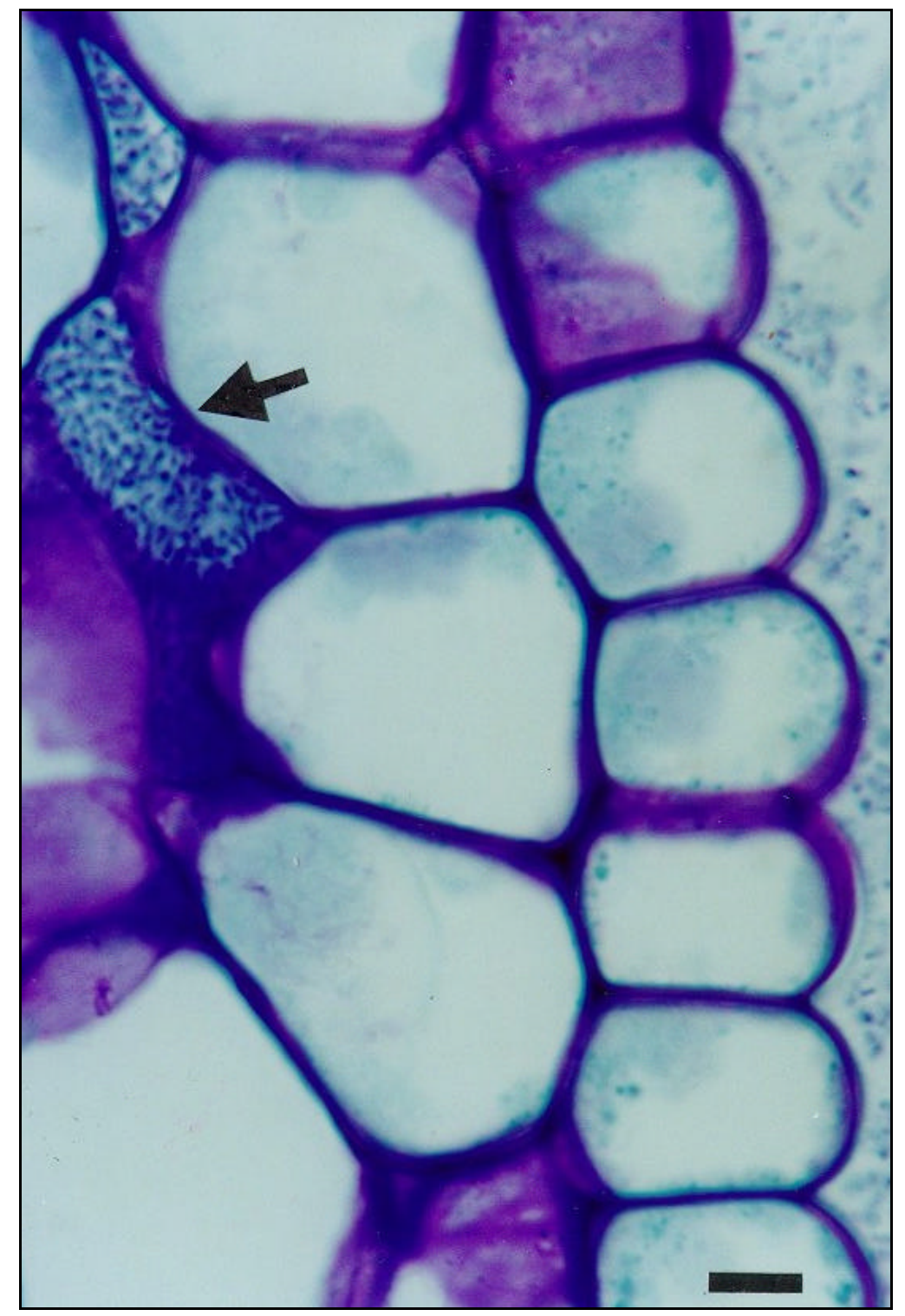

Figura 10 - Seção transversal de tecido inoculado com Agrobacterium. Na figura observamos uma grande quantidade de bactéria por todo o tecido (barra $=7.4 \mu \mathrm{m})$. 


\subsection{Susceptibilidade de diferentes espécies de Eucalyptus a agentes seletivos.}

Uma das condições necessárias ao sucesso na obtenção de plantas transgênicas é a capacidade de selecioná-las. A seleção pode ser realizada pelo uso de genes que conferem resistência à antibióticos ou herbicidas nas células transformadas ou mesmo pelo uso do próprio gene de interesse (Wilmink et al., 1993). Neste estudo foi avaliado o efeito de dois antibióticos do grupo aminoglicosilados sobre a capacidade de regeneração de sete espécies de eucalipto e do híbrido entre Eucalyptus grandis e Eucalyptus urophylla (GXU).

Pelos resultados da Tabela 1, observa-se uma grande variabilidade quanto à resposta dos diferentes genótipos de Eucalyptus aos antibióticos do grupo dos aminoglicosilados. As espécies que apresentam maior susceptibilidade à canamicina e geneticina foram: E. robusta e E. saligna. Já E. dunni e E. grandis apresentaram susceptibilidade diferencial para geneticina e canamicina.

A partir destas informações podemos apontar quais as espécies de Eucalyptus mais indicadas para serem usadas nos experimentos de transformação, uma vez que apresentam susceptibilidade aos agentes seletivos testados, assim como encontrar quais as concentrações de antibióticos que são ideais para realizar uma seleção eficiente de plantas transformadas. 
Tabela 1. Porcentagem de plantas vivas aos 60 dias em meio com agente seletivo.

\begin{tabular}{lcccccccc} 
& GXU & E robusta & E dunni & E urophyl & E pellita & E brassia & E saligna & E grandis \\
\hline Controle & 100 & 100 & 100 & 100 & 100 & 100 & 100 & 100 \\
Canamicina & 46.7 & 2.7 & 11.3 & 40.6 & 1.8 & 15.6 & 3.9 & 34.8 \\
Geneticina & 3.2 & 1.5 & 1.6 & 6.2 & 2.8 & 10.9 & 1.1 & 1.5 \\
\hline
\end{tabular}

As dosagens usadas foram: $100 \mathrm{mgL}^{-1}$ de canamicina e $10 \mathrm{mgL}^{-1}$ de geneticina.

\subsection{Susceptibilidade de diferentes progênies de Eucalyptus a agentes seletivos.}

Dando continuidade ao estudo sobre o comportamento do eucalipto a agentes seletivos do grupo dos aminoglicosilados, foi avaliada a capacidade de regeneração de sete progênies de Eucalyptus grandis germinadas em geneticina ou canamicina. Os resultados elucidam informações interessantes sobre os efeitos de ambos os antibióticos nas progênies de Eucalyptus. As Figuras 11 e 12, ilustram a curva de mortalidade de diferentes progênies de Eucalyptus grandis.

A família $E$. grandis 28 demonstrou uma alta susceptibilidade a ambos os antibióticos com $100 \%$ de mortalidade aos 35 dias após a semeadura. Por outro lado, a família E. grandis 26 apresentou maior tolerância, principalmente a geneticina. Já as outras progênies demonstraram uma severa mortalidade observada apenas aos 50 dias após a germinação. A geneticina foi mais eficiente para indução de mortalidade já nos primeiros dias após a germinação em canamicina. 


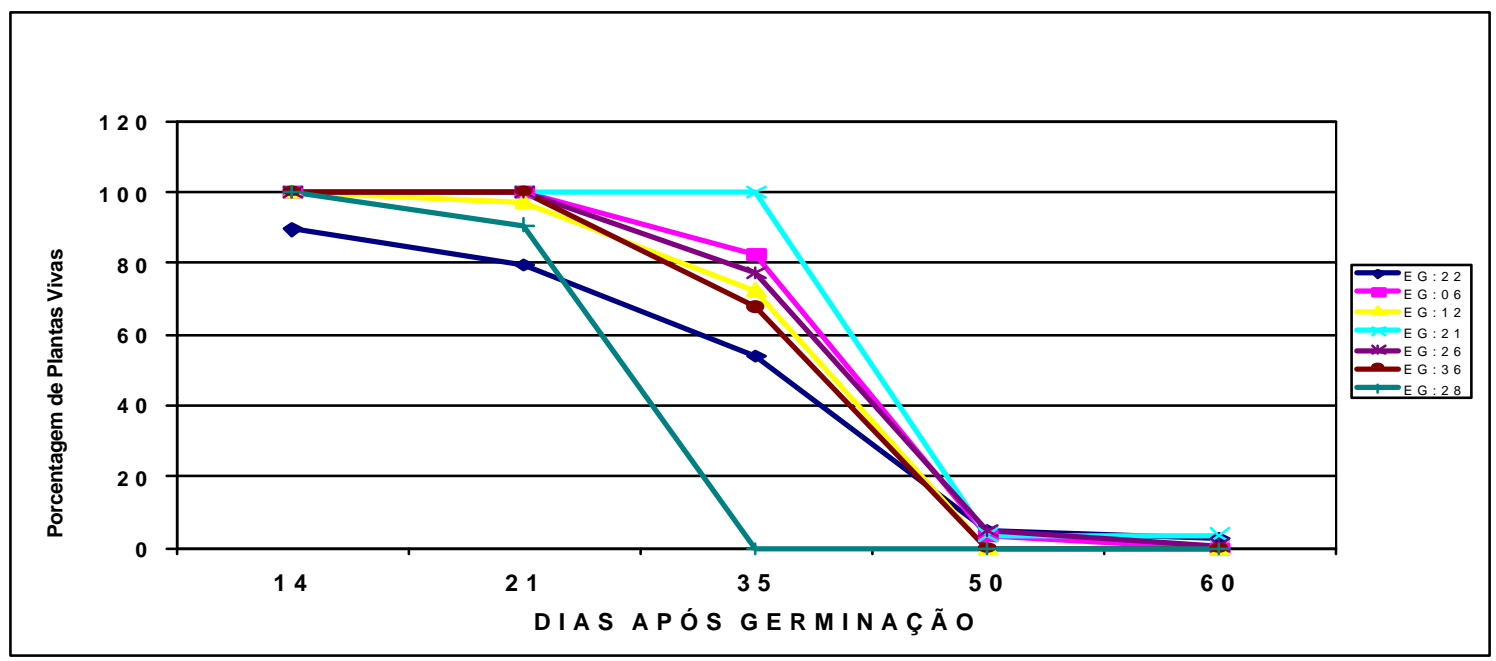

Figura 11 - Avaliação de diferentes progênies de Eucalyptus grandis a canamicina. A dosagem de canamicina usada foi de $100 \mathrm{mgL}^{-1}$. As avaliações foram realizadas ao longo do tempo; 14, 21, 35, 50 e 60 dias após a germinação, considerando-se a porcentagem de plantas vivas.

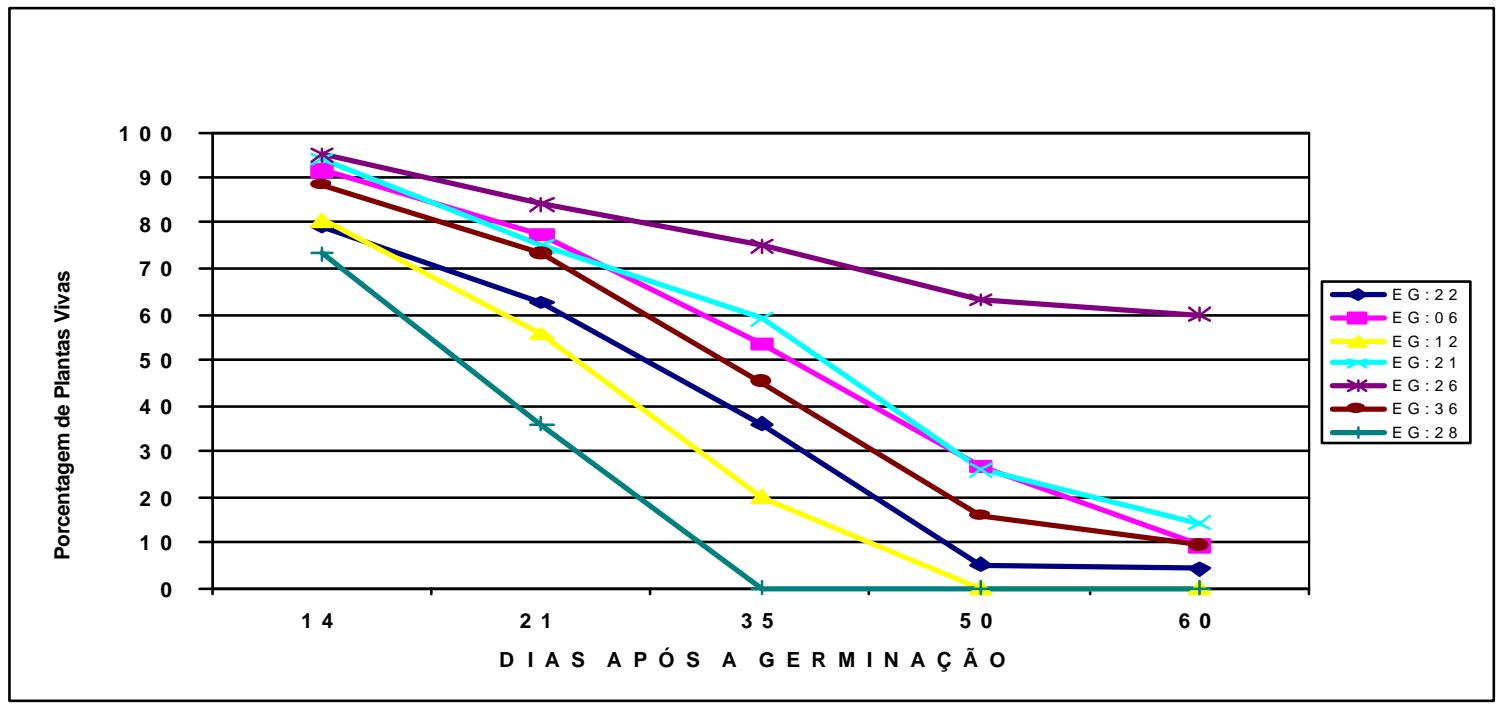

Figura 12 - Avaliação de diferentes progênies de Eucalyptus grandis à geneticina. A dosagem de geneticina usada foi de $10 \mathrm{mgL}^{-1}$. As avaliações foram realizadas ao longo do tempo; 14, 21, 35, 50 e 60 dias após a germinação, considerando-se a porcentagem de plantas vivas. 


\subsection{Seleção de clones susceptíveis a agentes seletivos}

Com base na variabilidade genética que existe dentro de uma população foi realizado um experimento para selecionar entre dez clones, um que apresente características favoráveis à transformação genética, alta taxa de regeneração a partir de folhas e susceptibilidade a agentes seletivos do grupo dos aminoglicosilados.

Dentre os dez clones avaliados, três destacaram-se por apresentarem duas características favoráveis à transformação: alta taxa de regeneração e susceptibilidade a agentes seletivos do grupo dos aminoglicosilados. Na Figura 13, podemos observar que os clones 1, 4 e 6 apresentaram uma taxa de regeneração superior a $70 \%$ e nas Figuras 14 e 15 podemos observar que os clones também apresentam alta susceptibilidade à geneticina e canamicina. $\mathrm{O}$ clone 7 apresentou também alta susceptibilidade à canamicina e à geneticina, porém a taxa de regeneração não foi boa. Nos experimentos de combinação entre geneticina e canamicina não observou-se a presença de "escapes" ou seja explantes que apresentam resistência ao antibiótico; a taxa mortalidade dos clones 1,4 e 6 , foi de $100 \%$.

Estes materiais são particularmente interessantes, pois alem de apresentarem alta taxa de regeneração possuem uma resposta uniforme aos agentes seletivos, auxiliando assim a seleção de transformantes nos experimentos de transformação genética. 


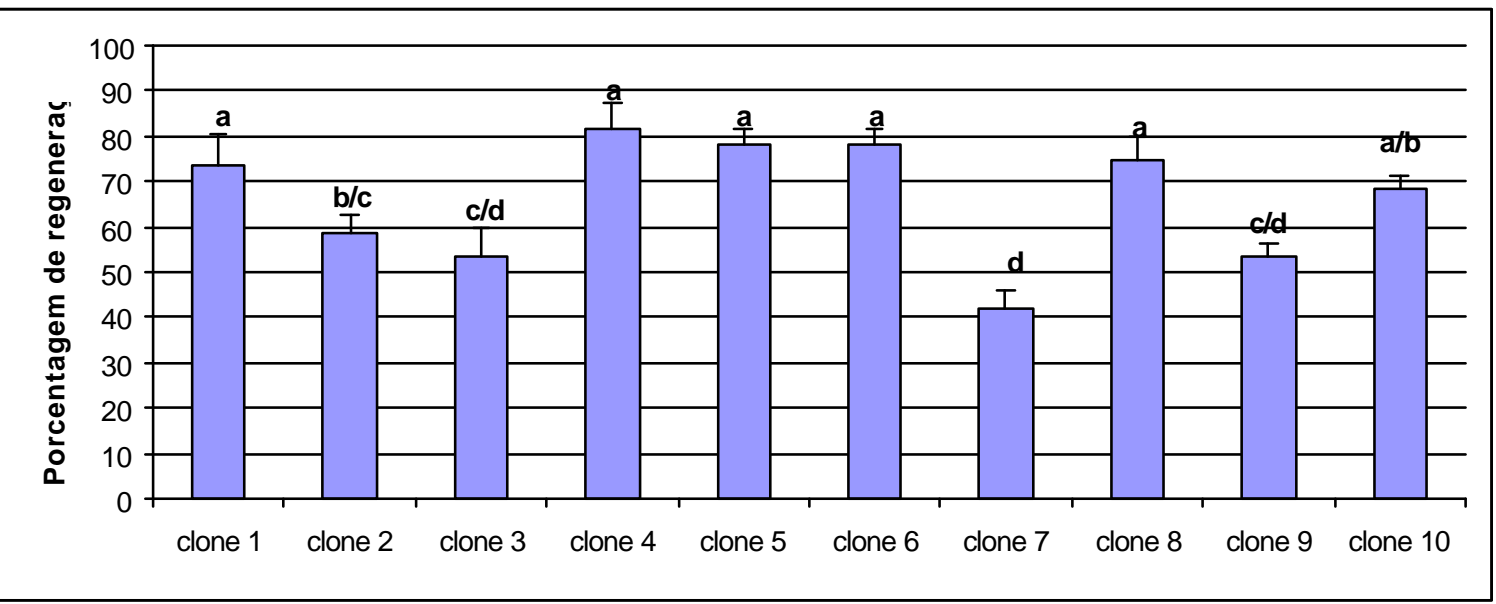

Figura 13 - Avaliação da taxa de regeneração dos clones. Médias com a mesma letra não diferem significativamente ao nível de $5 \%$ pelo Teste de Tukey. As barras verticais indicam o desvio padrão da média.

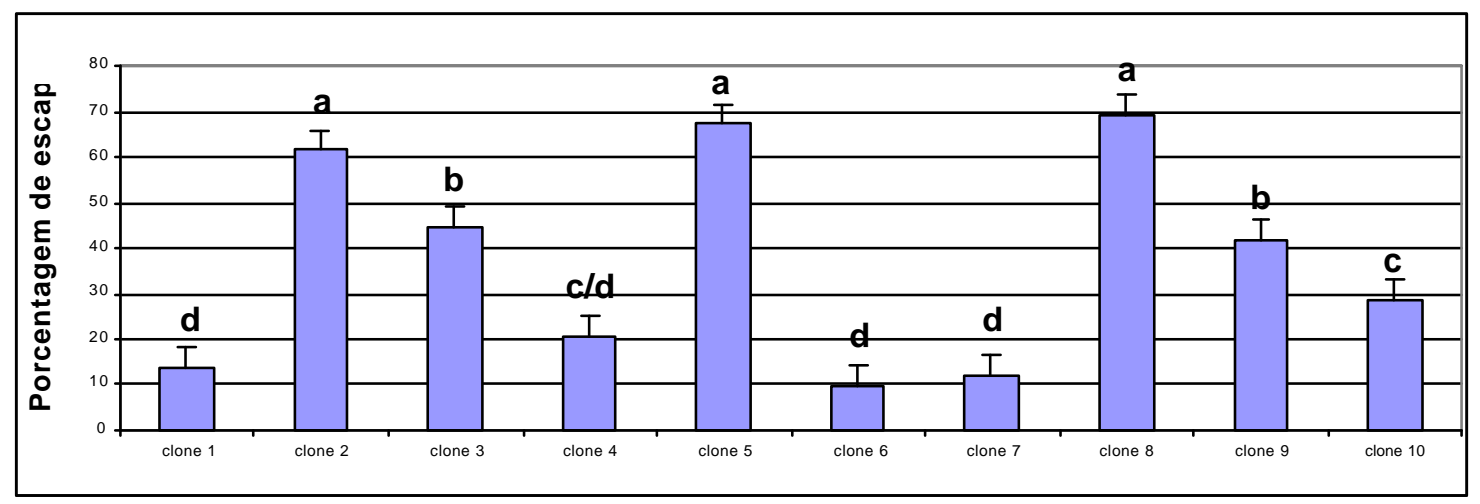

Figura 14 - Avaliação da susceptibilidade de clones a geneticina $\left(10 \mathrm{mgL}^{-1}\right)$. Médias com a mesma letra não diferem significativamente ao nível de $5 \%$ pelo Teste de Tukey. As barras verticais indicam o desvio padrão da média. 


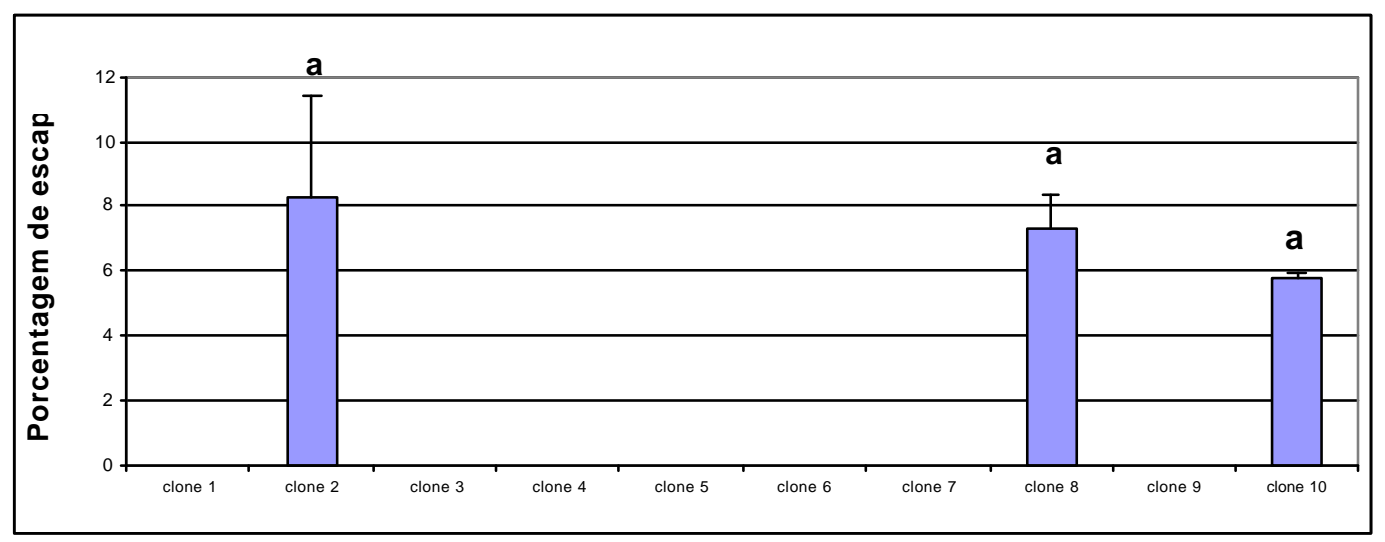

Figura 15 - Avaliação da susceptibilidade dos clones àcombinação de geneticina $\left(5 \mathrm{mgL}^{-1}\right)$ e canamicina $\left(25 \mathrm{mgL}^{-1}\right)$.

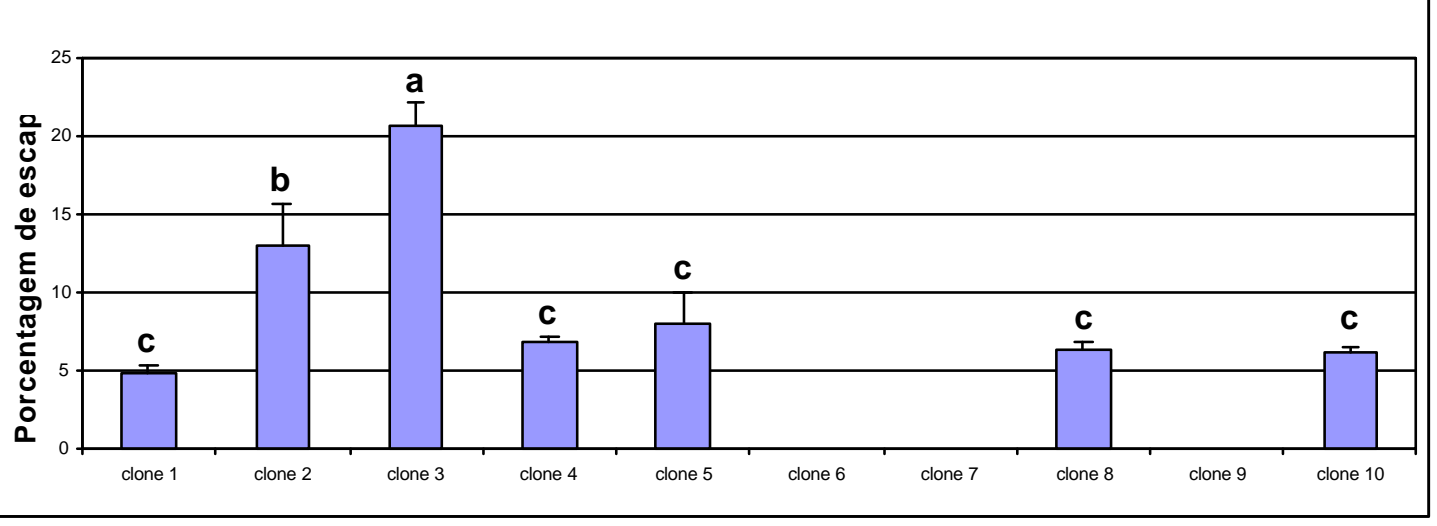

Figura 16 - Avaliação da susceptibilidade dos clones à canamicina $\left(50 \mathrm{mgL}^{-1}\right)$. Médias com a mesma letra não diferem significativamente ao nível de $5 \%$ pelo Teste de Tukey. As barras verticais indicam o desvio padrão da média. 


\subsection{Seleção de clones susceptíveis a transformação}

Dando continuidade à seleção de clones com características favoráveis à transformação, foram avaliados três clones, quanto a sua susceptibilidade a infecção por Agrobacterium. Os clones avaliados possuem características como taxa de regeneração superior a $70 \%$ e alta susceptibilidade a agentes seletivos.

O objetivo do experimento foi encontrar um clone que apresente as seguintes características: alta taxa de regeneração, susceptibilidade a agentes seletivos e à transformação por Agrobacterium. Dos três clones avaliados quanto à transformação por Agrobacterium, o clone 6 foi o que apresentou a melhor resposta (Figura 17) foi também o que apresentou a maior porcentagem de explantes e folhas com pontos azuis indicando a atividade da B glucuronidase.

Resultados semelhantes foram obtidos por Mullins et al. (1997) no qual trabalhando com 24 clones de Eucalyptus camaldulensis, observaram que entre eles existe uma resposta diferencial à susceptibilidade da Agrobacterium, sendo que apenas um teve a capacidade de gerar uma planta transformada. 


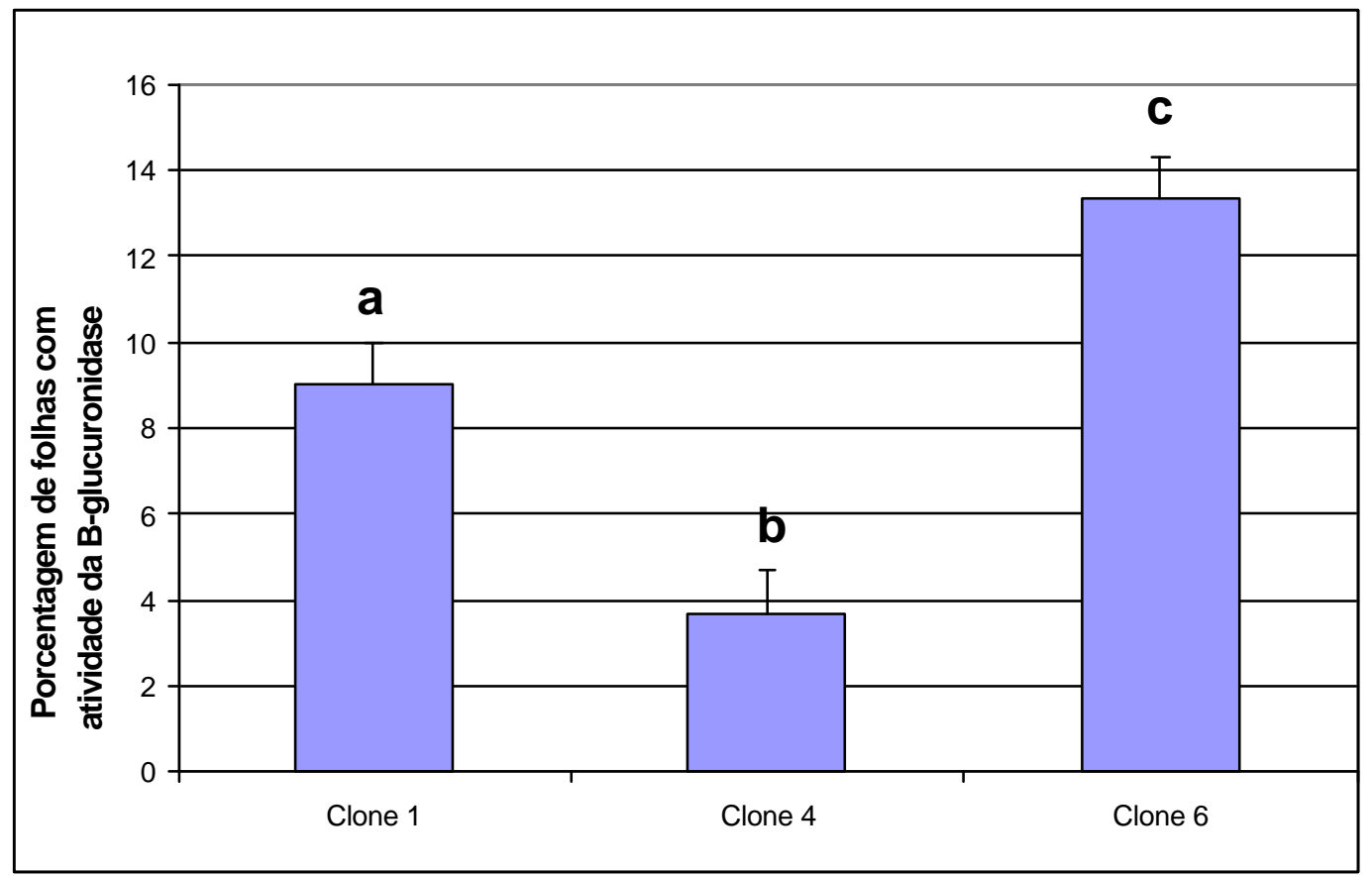

Figura 17 - Avaliação de clones quanto à susceptibilidade à transformação. Médias com a mesma letra não diferem significativamente ao nível de $5 \%$ pelo Teste de Tukey. As barras verticais indicam o desvio padrão da média.

\subsection{Efeito do tempo de sonicação}

Trick \& Finer (1997), trabalhando com diferentes explantes observaram que os tecidos diferem em sua resposta ao tratamento com SAAT. Um dos fatores que mais influenciam na transformação via SAAT é a duração do tempo de sonicação, há a necessidade de se determinar, qual o melhor tempo para cada tecido e espécie. Embora os tecidos respondam a um aumento do tempo de sonicação, deve-se considerar sua interferência na capacidade de 
regeneração do tecido em cultura de tecido. Joersbo \& Brunstedt (1992) observaram que intensidades muito alta de sonicação podem causar lise e conseqüentemente morte celular, influenciando na regeneração dos tecidos.

Desta forma desenvolveu-se um experimento onde foram avaliados os seguintes tempos de sonicação: 0, 30, 60, 90 e 120 segundos. Durante o experimento foi usado o clone 6 por este apresentar características favoráveis à transformação: alta taxa de regeneração, susceptibilidade a agentes seletivos e àtransformação com Agrobacterium. O uso de um clone na avaliação de um sistema de transformação tem como vantagem reduzir o desvio padrão da média pois não existe variação genética entre os explantes, possibilitando maior confiabilidade aos resultados.

A maior freqüência de plantas com atividade da Bglucuronidase, ou seja, expressando o gene uidA foi observada quando os explantes foram submetidos a 120 segundos de sonicação, demonstrado na Figura 18. Porém, quando os explantes são submetidos a um tempo de sonicação superior a 60 segundos há uma grande inibição de sua regeneração; os tecidos apresentam regiões fortemente oxidadas e mortas.

Os resultados indicam que o tempo de sonicação de 60 segundos é o que apresenta a maior viabilidade de uso em experimentos de transformação de folhas de eucalipto, pois além de não comprometer a regeneração do explante, o número dos mesmos, com pontos de coloração azulada, referentes à atividade da B-glucuronidase é maior. Tempos de sonicação inferiores a 60 
segundos apresentaram uma menor porcentagem de pontos de coloração azulada nas folhas dos explantes. Não há diferença significativa entre o material submetido a 30 segundos de sonicação e o controle, embora com a sua realização houve um aumento da porcentagem de explantes que apresentaram atividade da Bglucuronidase.

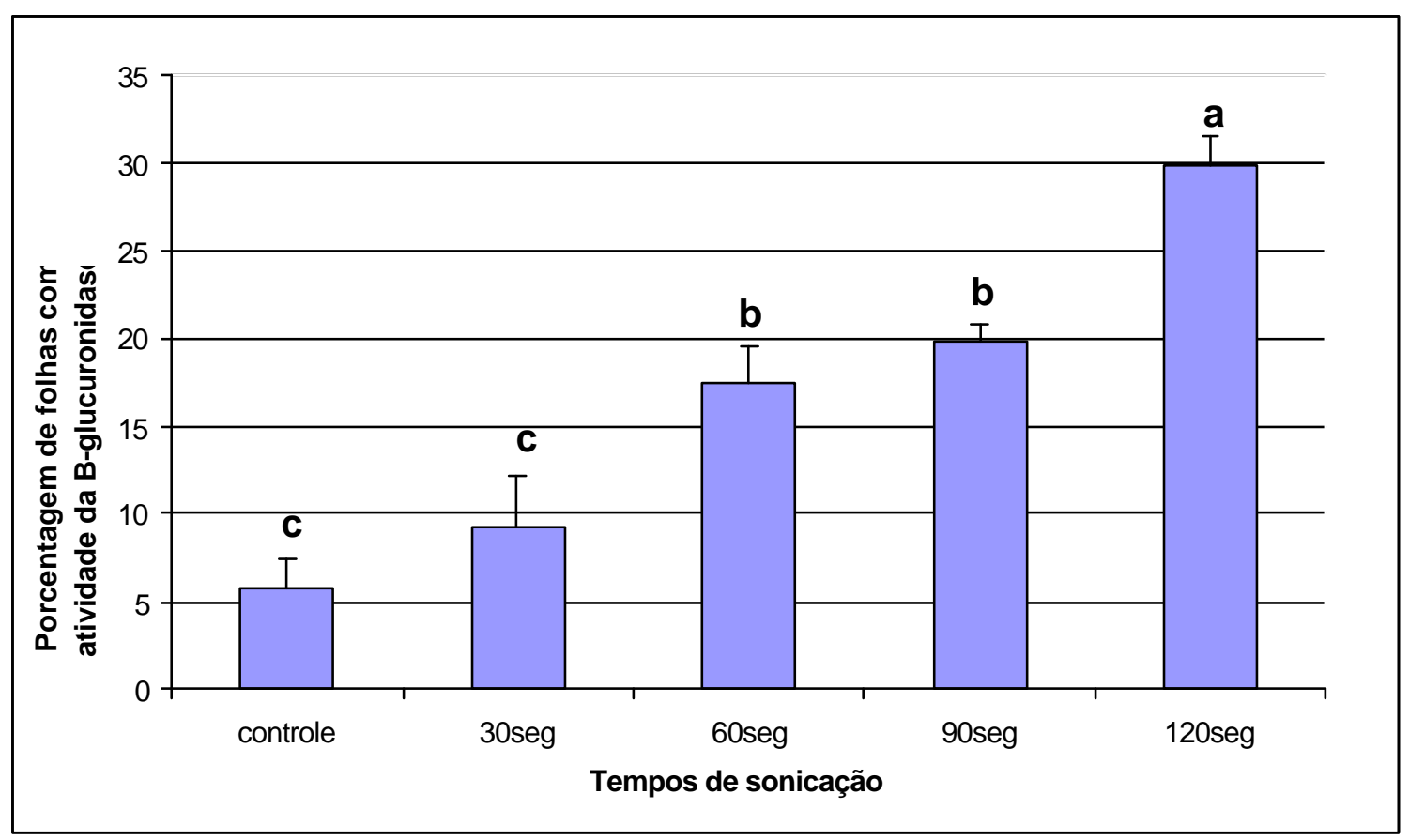

Figura 18 - Avaliação de diferentes tempos de sonicação. Plântulas de 15 dias, do clone 6, submetidas a sonicação e inoculação com Agrobacterium. Avaliação realizada aos 7 dias após a inoculação. Médias com a mesma letra não diferem significativamente ao nível de $1 \%$ pelo Teste de Tukey. As barras verticais indicam o desvio padrão da média. 


\subsection{Efeito da pós-sonicação}

Baseado nos resultados obtidos anteriormente, onde avaliou-se o efeito do tempo na eficiência da transformação via SAAT, foi realizado um experimento o qual teve como objetivo avaliar o efeito de uma sonicação adicional na eficiência de transformação por Agrobacterium. Foram avaliados os seguintes tempos de sonicação adicional: $0,10,30,60$ e 90 segundos. $O$ tempo de 60 segundos de sonicação preliminar foi escolhido por ter apresentado a melhor resposta quando foi avaliado o efeito do tempo na transformação via SAAT. Durante o experimento foi usado como fonte de explante o clone 6 por apresentar características favoráveis àtransformação.

Pela Figura 19, observa-se que submetendo os explantes a uma sonicação adicional, ocorre um aumento da porcentagem de explantes com pontos de coloração azul, referentes à atividade da B-glucuronidase.

O tempo de 10 segundos foi o que apresentou a melhor viabilidade de uso, pois a regeneração do material não ficou comprometida e a porcentagem de explantes com atividade $B$ glucuronidase foi maior.

Já os tempos de pós-sonicação superiores a 10 segundos afetam a regeneração dos tecidos os quais apresentaram-se oxidados e em alguns casos mortos. 


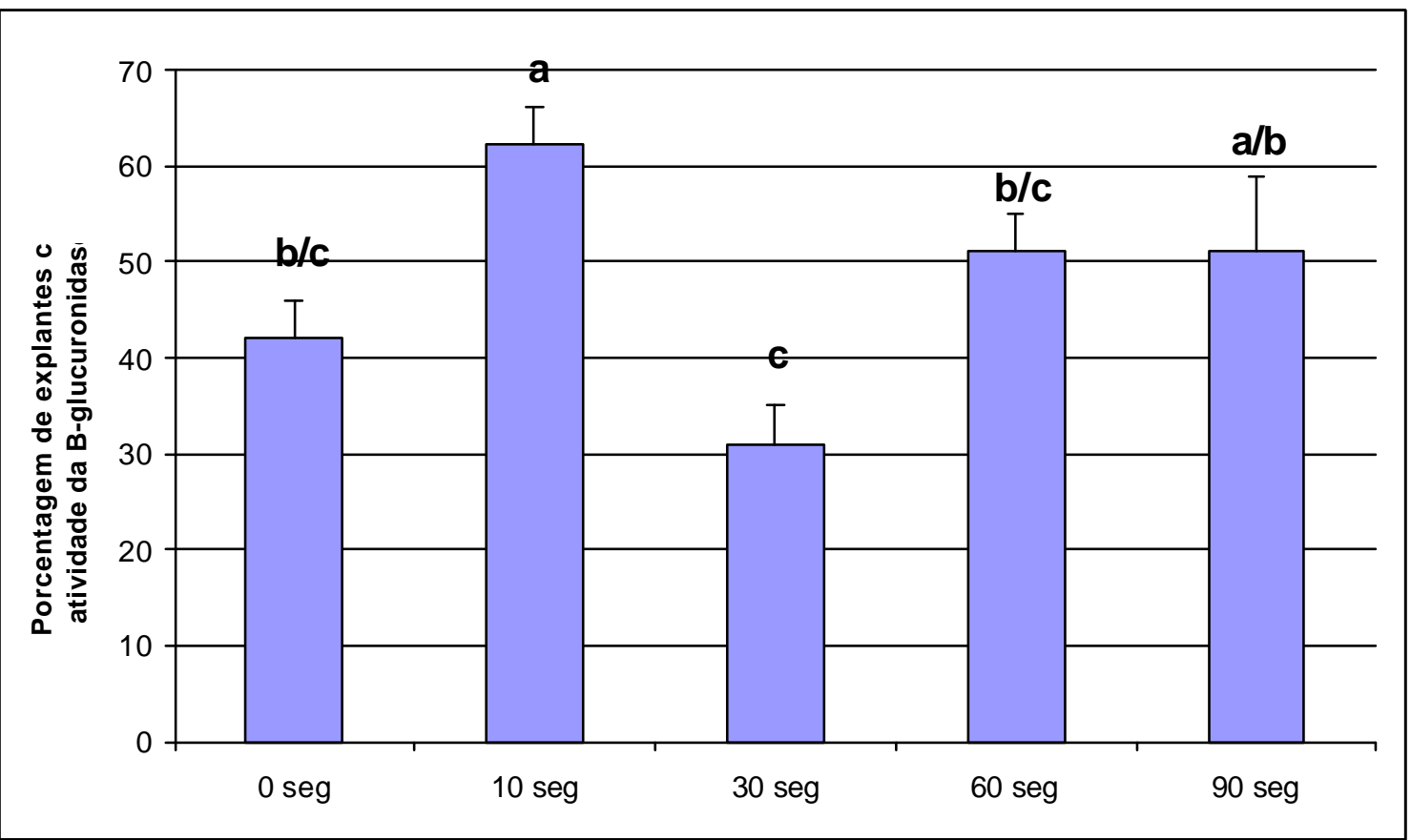

Figura 19 - Avaliação de diferentes tempos de pós sonicação. Plântulas de 15 dias do clone 6 submetidas a uma pré-inoculação de 60 segundos inoculadas com a bactéria e sonicadas por: 0, 10, 30, 60 e 90 segundos. Avaliação realizada aos 7 dias após a sonicação. 


\section{CONCLUSÕES}

- Nos experimentos de agrobiobalística realizados em explantes com acumulo de gemas axilares não foi observado nenhum broto transgênico, demonstrando que seu uso não é viável.

- O estudo histológico e anatômico mostrou que a região meristemática, que forma as gemas axilares, é superficial e não possui impedimento físico para que ocorra a transformação.

- O estudo histológico do gene uidA, confirmou que apenas células diferenciadas em Eucalyptus são transformadas por Agrobacterium.

- A avaliação da susceptibilidade de diferentes espécies de Eucalyptus e progênie de Eucalyptus grandis, permitiu constatar que entre espécie e progênie existe uma grande variabilidade a agentes seletivos. Podendo com isso direcionar o uso de espécies usadas em programas de transformação genética.

- A avaliação dos clones possibilitou a seleção de um clone com características favoráveis à transformação: alta taxa de 
regeneração, susceptibilidade a transformação e a agentes seletivos.

- O tempo de sonicação de 60 segundos, seguido por uma sonicação adicional com a bactéria é o mais indicado para ser realizado em experimentos de transformação genética de Eucalyptus via Agrobacterium. 
ANEXOS 


\section{A1 PREPARO DOS MEIOS DE CULTURA}

\section{Meio MS}

\begin{tabular}{|c|c|c|}
\hline Categoria & & Quantidade \\
\hline Macronutrientes (g/L) & $\begin{array}{l}\mathrm{NH}_{4} \mathrm{NO}_{3} \\
\mathrm{KNO}_{3} \\
\mathrm{CaCl}_{2} \cdot 2 \mathrm{H}_{2} \mathrm{O} \\
\mathrm{MgSO}_{4} \cdot 7 \mathrm{H}_{2} \mathrm{O} \\
\mathrm{KH}_{2} \mathrm{PO}_{4}\end{array}$ & $\begin{array}{l}1.65 \\
1.9 \\
0.44 \\
0.37 \\
0.17\end{array}$ \\
\hline Micronutrientes (mg/L) & $\begin{array}{l}\mathrm{ZnSO}_{4} \\
\mathrm{H}_{3} \mathrm{BO}_{3} \\
\mathrm{MnSO}_{4} \cdot 4 \mathrm{H}_{2} \mathrm{O} \\
\mathrm{CuSO}_{4} \cdot 5 \mathrm{H}_{2} \mathrm{O} \\
\mathrm{KI} \\
\mathrm{Na}_{2} \mathrm{MoO}_{4} \cdot 2 \mathrm{H}_{2} \mathrm{O} \\
\mathrm{CoCl}_{2} \cdot 6 \mathrm{H}_{2} \mathrm{O}\end{array}$ & $\begin{array}{l}8.6 \\
6.2 \\
16.9 \\
0.025 \\
0.83 \\
0.25 \\
0.025\end{array}$ \\
\hline Fe EDTA (mg) & $\begin{array}{l}\mathrm{FeSO}_{4.7 \mathrm{H}_{2} \mathrm{O}} \\
\mathrm{Na}_{2} \text { EDTA. } 2 \mathrm{H}_{2} \mathrm{O}\end{array}$ & $\begin{array}{l}41.3 \\
27.8\end{array}$ \\
\hline Vitamina $(\mu \mathrm{L})$ & White & 100 \\
\hline $\begin{array}{l}\text { Fonte de Carbono (\%) } \\
\text { Agente solidificante (\%) }\end{array}$ & $\begin{array}{l}\text { Sacarose } \\
\text { Agar }\end{array}$ & $\begin{array}{l}2 \\
0.6\end{array}$ \\
\hline $\mathrm{pH}$ & & 5.8 \\
\hline
\end{tabular}




\section{Meio de indução da formação de calos}

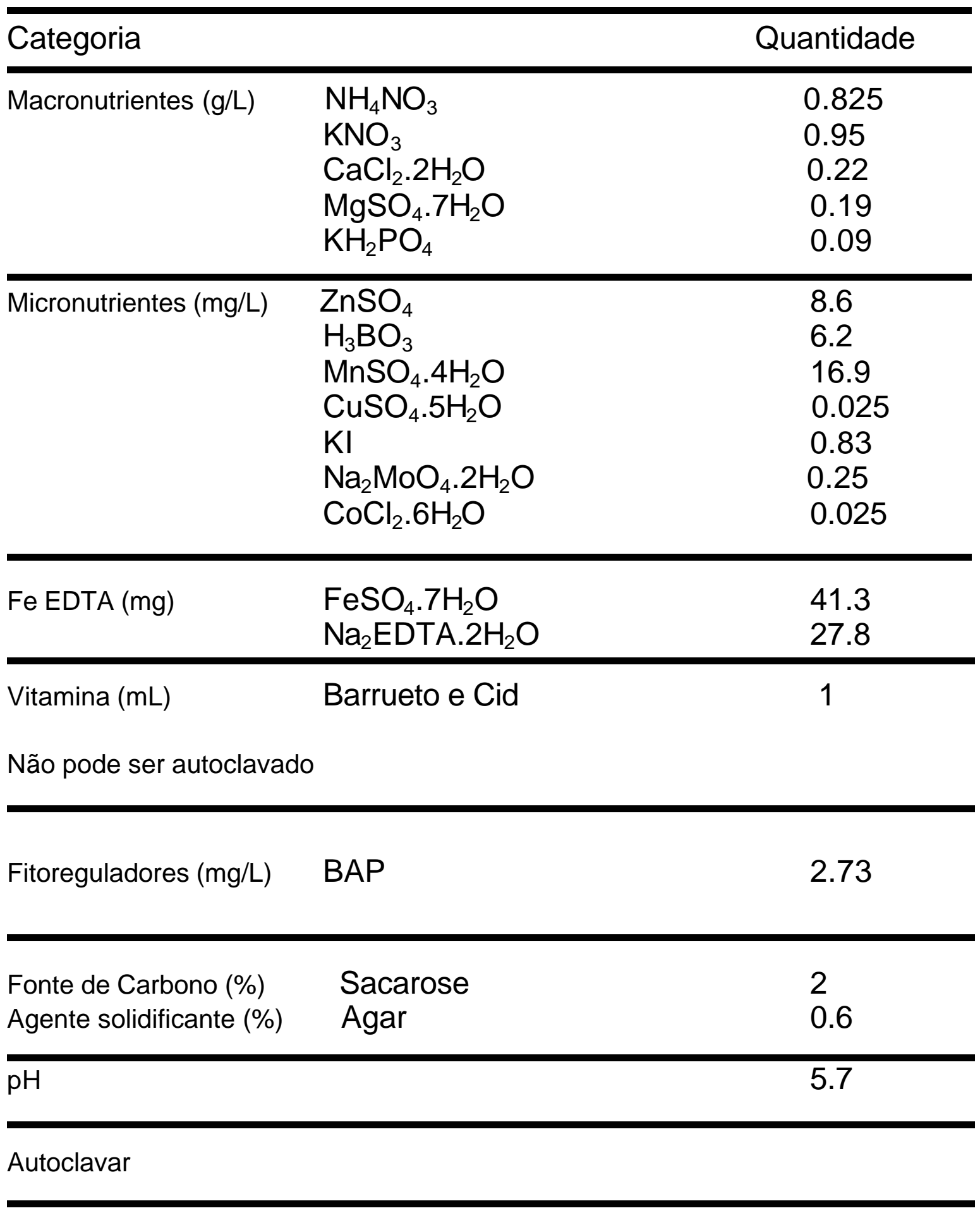




\section{Meio 0.5 TDZ}

\begin{tabular}{|c|c|c|}
\hline Categoria & & Quantidade \\
\hline Macronutrientes (g/L) & $\begin{array}{l}\mathrm{NH}_{4} \mathrm{NO}_{3} \\
\mathrm{KNO}_{3} \\
\mathrm{CaCl}_{2} \cdot 2 \mathrm{H}_{2} \mathrm{O} \\
\mathrm{MgSO}_{4} \cdot 7 \mathrm{H}_{2} \mathrm{O} \\
\mathrm{KH}_{2} \mathrm{PO}_{4}\end{array}$ & $\begin{array}{l}0.825 \\
0.95 \\
0.22 \\
0.19 \\
0.09\end{array}$ \\
\hline Micronutrientes (mg/L) & $\begin{array}{l}\mathrm{ZnSO}_{4} \\
\mathrm{H}_{3} \mathrm{BO}_{3} \\
\mathrm{MnSO}_{4} \cdot 4 \mathrm{H}_{2} \mathrm{O} \\
\mathrm{CuSO} \cdot 5 \mathrm{H}_{2} \mathrm{O} \\
\mathrm{KI} \\
\mathrm{Na}_{2} \mathrm{MoO}_{4} \cdot 2 \mathrm{H}_{2} \mathrm{O} \\
\mathrm{CoCl}_{2} \cdot 6 \mathrm{H}_{2} \mathrm{O}\end{array}$ & $\begin{array}{l}8.6 \\
6.2 \\
16.9 \\
0.025 \\
0.83 \\
0.25 \\
0.025\end{array}$ \\
\hline Fe EDTA (mg) & $\begin{array}{l}\mathrm{FeSO}_{4} .7 \mathrm{H}_{2} \mathrm{O} \\
\mathrm{Na}_{2} \mathrm{EDTA} .2 \mathrm{H}_{2} \mathrm{O}\end{array}$ & $\begin{array}{l}41.3 \\
27.8\end{array}$ \\
\hline $\begin{array}{l}\text { Vitamina }(\mathrm{mL}) \\
\text { Não pode ser autoclado }\end{array}$ & Barrueto e Cid & 1 \\
\hline Fitoreguladores (mg) & $\begin{array}{l}\text { TDZ } \\
\text { ANA } \\
\text { BAP }\end{array}$ & $\begin{array}{l}0.5 \\
0.465 \\
1.2\end{array}$ \\
\hline $\begin{array}{l}\text { Fonte de Carbono (\%) } \\
\text { Agente solidificante (\%) }\end{array}$ & $\begin{array}{l}\text { Sacarose } \\
\text { Agar }\end{array}$ & $\begin{array}{l}3 \\
0.6\end{array}$ \\
\hline $\mathrm{pH}$ & & 5.7 \\
\hline
\end{tabular}




\section{Meio de alongamento (AI)}

\begin{tabular}{|c|c|c|}
\hline Categoria & & Quantidade \\
\hline Macronutrientes (g/L) & $\begin{array}{l}\mathrm{NH}_{4} \mathrm{NO}_{3} \\
\mathrm{KNO}_{3} \\
\mathrm{CaCl}_{2} \cdot 2 \mathrm{H}_{2} \mathrm{O} \\
\mathrm{MgSO}_{4} \cdot 7 \mathrm{H}_{2} \mathrm{O} \\
\mathrm{KH}_{2} \mathrm{PO}_{4}\end{array}$ & $\begin{array}{l}1.65 \\
1.9 \\
0.44 \\
0.37 \\
0.17\end{array}$ \\
\hline Micronutrientes (mg/L) & $\begin{array}{l}\mathrm{ZnSO}_{4} \\
\mathrm{H}_{3} \mathrm{BO}_{3} \\
\mathrm{MnSO}_{4} \cdot 4 \mathrm{H}_{2} \mathrm{O} \\
\mathrm{CuSO} \cdot 5 \mathrm{H}_{2} \mathrm{O} \\
\mathrm{KI} \\
\mathrm{Na}_{2} \mathrm{MoO}_{4} \cdot 2 \mathrm{H}_{2} \mathrm{O} \\
\mathrm{CoCl}_{2} \cdot 6 \mathrm{H}_{2} \mathrm{O}\end{array}$ & $\begin{array}{l}8.6 \\
6.2 \\
16.9 \\
0.025 \\
0.83 \\
0.25 \\
0.025\end{array}$ \\
\hline Fe EDTA (mg) & $\begin{array}{l}\mathrm{FeSO}_{4} .7 \mathrm{H}_{2} \mathrm{O} \\
\mathrm{Na}_{2} \mathrm{EDTA}_{2} 2 \mathrm{H}_{2} \mathrm{O}\end{array}$ & $\begin{array}{l}41.3 \\
27.8\end{array}$ \\
\hline Vitamina (mL) & MM & 100 \\
\hline Fitoreguladores (mg/L) & $\begin{array}{l}\text { BAP } \\
\text { IBA }\end{array}$ & $\begin{array}{l}0.1 \\
0.2\end{array}$ \\
\hline $\begin{array}{l}\text { Fonte de Carbono }(\%) \\
\text { Agente solidificante }(\%)\end{array}$ & $\begin{array}{l}\text { Sacarose } \\
\text { Agar }\end{array}$ & $\begin{array}{l}2 \\
0.6\end{array}$ \\
\hline $\mathrm{pH}$ & & 5.8 \\
\hline
\end{tabular}




\section{Meio $A B$, crescimento da bactéria}

\begin{tabular}{lcc}
\hline Categoria & estoques & Quantidade \\
\hline Tampão $(\mathrm{g} / \mathrm{L})$ & $\mathrm{NaH}_{2} \mathrm{PO}_{4}$ & 20 \\
& $\mathrm{~K}_{2} \mathrm{HPO}_{4}$ & 60
\end{tabular}

Ajustar para $\mathrm{pH}=6.6$

\begin{tabular}{lll}
\hline Sais $(\mathrm{g} / \mathrm{L})$ & $\mathrm{NH} 4 \mathrm{Cl}$ & 20 \\
& $\mathrm{MgSO}_{4}$ & 6 \\
$\mathrm{KCl}$ & 3 \\
& $\mathrm{CaCl}_{2}$ & 0.2 \\
& $\mathrm{FeSO}_{4} .7 \mathrm{H}_{2} \mathrm{O}$ & 0.005
\end{tabular}

Autoclavar ambos os estoques

Antibióticos

Higromicina

$50 \mathrm{mg} / \mathrm{L}$

Canamicina

$25 \mathrm{mg} / \mathrm{L}$

Filtrar em fluxo laminar.

Manter a $-20^{\circ} \mathrm{C}$

Para preparar 1 litro de meio, adiciona-se em 900ml de água destilada 5 gramas de glicose e 15 gramas de Ágar (meio sólido) seguida por autoclavagem. No fluxo laminar, adiciona-se 50 $\mathrm{mL}$ de Tampão $A B, 50 \mathrm{~mL}$ de sais $A B$ e os antibióticos. 


\section{A2 PREPARO DAS VITAMINAS}

Preparo da vitamina Barrueto e Cid (estoque de $50 \mathrm{~mL}$ )

\begin{tabular}{lc}
\hline Categoria & Quantidade \\
\hline Pantotenato de cálcio & $50 \mathrm{mg}$ \\
Piridoxina & $50 \mathrm{mg}$ \\
Tiamina & $50 \mathrm{mg}$ \\
Ácido nicotínico & $50 \mathrm{mg}$ \\
Inositol & $5 \mathrm{~g}$ \\
\hline
\end{tabular}

Filtrar em fluxo laminar

Manter na geladeira

Preparo da vitamina MM (estoque de 50ml)

\begin{tabular}{lc}
\hline Categoria & Quantidade \\
\hline Piridoxina & $0.06 \mathrm{mg}$ \\
Tiamina & $0.5 \mathrm{mg}$ \\
Ácido nicotínico & $0.125 \mathrm{mg}$ \\
Inositol & $5 \mathrm{~g}$ \\
\hline
\end{tabular}

Manter na geladeira 


\section{Preparo da vitamina White (estoque de $10 \mathrm{ml}$ )}

\begin{tabular}{lc}
\hline Categoria & Quantidade \\
\hline Piridoxina & $10 \mathrm{mg}$ \\
Tiamina & $50 \mathrm{mg}$ \\
Ácido nicotínico & $10 \mathrm{mg}$ \\
Glicina & $300 \mathrm{mg}$ \\
\hline Manter na geladeira &
\end{tabular}

\section{A3 PREPARO DA SOLUÇÃO DE KARNOVSKY}

Categoria

Quantidade

a) Glutaraldeído a 1\% em tampão fosfato $0.1 \mathrm{M} \mathrm{pH} 7.2$

$500 \mathrm{ml} / \mathrm{L}$

b) Paraformaldeído a $4 \%$ $200 \mathrm{ml} / \mathrm{L}$

c) Tampão fosfato $0.2 \mathrm{M} \mathrm{pH} 7.2$ $300 \mathrm{ml} / \mathrm{L}$

Conservar à $4^{\circ} \mathrm{C}$, no escuro

Preparo do Glutaraldeído a $1 \%$

Tampão fosfato $0.1 \mathrm{M} \mathrm{pH} 7.2$

Preparo do Formaldeído a 4\%

Água destilada aquecida a $60^{\circ}$

$200 \mathrm{ml}$ Acrescentar $8 \mathrm{~g}$ de paraformaldeído agitar por duas horas até dissolve-lo. Acrescentar gotas de hidróxido de sódio até a solução ficar límpida 


\section{A4 PREPARO DA SOLUÇÃO X- GLUC (200 ML)}

\begin{tabular}{lc}
\hline Categoria & Quantidade \\
\hline EDTA & $0.744 \mathrm{~g}$ \\
$\mathrm{NaH}_{2} \mathrm{PO}_{4} \cdot \mathrm{H}_{2} \mathrm{O}$ & $2.76 \mathrm{~g}$ \\
$\mathrm{~K}_{4} \mathrm{Fe}(\mathrm{CN})_{6} .3 \mathrm{H}_{2} \mathrm{O}$ & $0.0424 \mathrm{~g}$ \\
$\mathrm{~K}_{4} \mathrm{Fe}(\mathrm{CN})_{6}$ & $0.032 \mathrm{~g}$ \\
Triton-X-100 (1\%) & $0.200 \mathrm{~mL}$ \\
\hline
\end{tabular}

Agitar por 10 minutos, para dissolver;

Ajustar o $\mathrm{pH}$ para 7,0 com $\mathrm{NaOH}$;

Dissolver 100mg de X-Gluc/DMSO a solução;

Aliquotar e manter a $-20^{\circ} \mathrm{C}$ 


\section{REFERÊNCIAS BIBLIOGRÁFICAS}

ANDERSON, A.R.; MOORE, L.W. Host specificity in the genus Agrobacterium. Phytopathology, v.69, n.4, p.320-323, 1979.

ARAGÃO, F.J.L.; BARROS, L.M.G.; BRASILEIRO, A.C.M.; RIBEIRO, S.G.; SMITH, F.D.; SANFORD, J.C.; FARIA, J.C.; RECH, E.L. Inheritance of foreign genes in transgenic bean (Phaseolus vulgaris $\mathrm{L}$ ) co-transformed via particle bombardment. Theoretical and Applied Genetics, v.93, n.1-2, p.142-150, 1996.

BAILEY, M.A.; BOERMA, H.R.; PARROTT, W.A. Inheritance of Agrobacteriumtumefaciens-induced tumorigenesis of soybean. Crop Science, v.34, n.2, p.514-519, 1994.

BENEDDRA, T.; PICARD, C.; PETIT, A.; NESME, X. Correlation between susceptibility to crown gall and sensitivity to cytokinin in aspen cultivars. Phytopathology, v.86, n.2, p.225-231, 1996.

BERGMANN, B.A.; STOMP, A.M. Effect of host plant genotype and growth-rate on Agrobacterium- tumefaciens-mediated gall formation in Pinus-radiata. Phytopathology, v.82, n.12, p.1457-1462, 1992.

BEVAN, M.W.; FLAVELL, R.B.; CHILTON, M.D. A chimaeric antibioticresistance gene as a selectable marker for plant-cell transformation. Nature, v.304, n.5922, p.184-187, 1983.

BIDNEY, D.; SCELONGE, C.; MARTICH, J.; BURRUS, M.; SIMS, L.; HUFFMAN, G. Microprojectile bombardment of plant-tissues increases transformation frequency by Agrobacterium-tumefaciens. Plant Molecular Biology, v.18, n.2, p.301-313, 1992.

BOLTON, G.W.; NESTER, E.W.; GORDON, M.P. Plant phenolic-compounds induce expression of the Agrobacterium-tumefaciens loci needed for virulence. Science, v.232, n.4753, p.983-985, 1986. 
BOYNTON, J.E.; GILLHAM, N.W.; HARRIS, E.H.; HOSLER, J.P.; JOHNSON, A.M.; JONES, A.R.; RANDOLPHANDERSON, B.L.; ROBERTSON, D.; KLEIN, T.M.; SHARK, K.B.; SANFORD, J.C. Chloroplast transformation in Chlamydomonas with high-velocity microprojectiles. Science, v.240, n.4858, p.1534-1538, 1988.

BRACELPA Avaliação do Setor de Celulose e papel. htt://www.bracelpa.com.br (agosto 2000).

BRASILEIRO, A.C.M.; ARAGÃO, F.J.L.; ROSSI, S.; DUSI, D.M.A.; BARROS, L.M.G.; RECH, E.L. Susceptibility of common and tepary beans to Agrobacterium spp strains and improvement of Agrobacterium-mediated transformation using microprojectile bombardment. Journal of the American Society for Horticultural Science, v.121, n.5, p.810-815, 1996.

CHARLES, T.C.; JIN, S.G.; NESTER, E.W. 2-component sensory transduction systems in phytobacteria. Annual Review of Phytopathology, v.30, p.463484, 1992.

CHILTON, M.D.; DRUMMOND, M.H.; MERLO, D.J.; SCIAKY, D.; MONTOYA, A.L.; GORDON, M.P.; NESTER, E.W. Stable incorporation of plasmid DNA into higher plant-cells: molecular basis of crown gall tumorigenesis. Cell, v.11, n.2, p.263-271, 1977.

CRESSWELL, R. D.; BOURLAY, M.; FLANCLET, A. vegetative propagation of Eucalyptus. Tissue Culture in Forestry. Dordrecht, Martinus Nüyhoff. 1985. cap.6, p.45-72.

CRUZ, N. H.; MOREIRA-FILHO, C. A.; SILVA, M. E. Avaliação do impacto econômico das biotecnologias no setor de celulose e papel. São Paulo: FIPE,1988. p. 1 -9.

DECLEENE, M.; DELEY, J. Host range of crown gall. Botanical Review, v.42, n.4, p.389-466, 1976.

DEKATHEN, A.; JACOBSEN, H.J. Cell competence for Agrobacteriummediated DNA transfer in Pisum-sativum L. Transgenic Research, v.4, n.3, p.184-191, 1995.

DILLEN, W.; DE CLERCQ, J.; KAPILA, J.; ZAMBRE, M.; VAN MONTAGU, M.; ANGENON, G. The effect of temperature on Agrobacterium tumefaciensmediated gene transfer to plants. Plant Journal, v.12, n.6, p.1459-1463, 1997. 
DYE, F.; BERTHELOT, K.; GRIFFON, B.; DELAY, D.; DELMOTTE, F.M. Alkylsyringamides, new inducers of Agrobacterium tumefaciens virulence genes. Biochimie, v.79, n.1, p.3-6, 1997.

ELDRIDGE, K.; DAVIDSON, J.; HARWOOD, C., VAN WYK, G. Domestication and breeding. Oxford: Clarendon Press, 1993. p.228-246.

ENGSTROM, P.; ZAMBRYSKI, P.; VANMONTAGU, M.; STACHEL, S. Characterization of Agrobacterium-tumefaciens virulence proteins induced by the plant factor acetosyringone. Journal of Molecular Biology, v.197, n.4, p.635-645, 1987.

FILICHKIN, S.A.; GELVIN, S.B. Formation of a putative relaxation intermediate during T-DNA processing directed by the Agrobacterium-tumefaciens VirD1,D2 endonuclease. Molecular Microbiology, v.8, n.5, p.915-926. 1993.

FINER, J.J.; MCMULLEN, M.D. Transformation of cotton (Gossypium-hirsutumL) via particle bombardment. Plant Cell Reports, v.8, n.10, p.586-589. 1990.

FOX, T.D.; SANFORD, J.C.; MCMULLIN, T.W. Plasmids can stably transform yeast mitochondria lacking endogenous mt-DNA. Proceedings of the National Academy of Sciences of the United States of America, v.85, n.19, p.7288-7292, 1988.

FRALEY, R.T.; ROGERS, S.G.; HORSCH, R.B.; SANDERS, P.R.; FLICK, J.S.; ADAMS, S.P.; BITTNER, M.L.; BRAND, L.A.; FINK, C.L.; FRY, J.S.; GALLUPPI, G.R.; GOLDBERG, S.B.; HOFFMANN, N.L.; WOO, S.C. Expression of bacterial genes in plant-cells. Proceedings of the National Academy of Sciences of the United States of America-Biological Sciences, v.80, n.15, p.4803-4807, 1983.

FRIZZEL, L. A. Biological effects of acoustical cavitation. In Suslick, K. (Ed.), Ultrasound, its Chemical, Physical, and Biological Effects Weinheim, Germany: VCH Publishers, 1988. p. 123-161.

FULLNER, K.J.; NESTER, E.W. Temperature affects the T-DNA transfer machinery of Agrobacterium tumefaciens. Journal of Bacteriology, v.178, n.6, p.1498-1504, 1996

GONZALEZ, E. R.; ANDRADE, A.; BERTOLO, A. L.; LACERDA, G. C.; CARNEIRO, R. T.; DEFÁVARI, V. A. P.; LABATE, C. A. The efficiency of aminoglycoside antibiotics in the regeneration and selection of Eucalyptus spp. International Conference: Eucalyptus in the Mediterranean Basin: Perspectives and New Utilisations. Italy October 2000. 
KARNOVSKY, M. J. A formaldehyde fixative of high osmolality for use in electron microscopy. Journal of Cell Biology, v.27, p.137-138, 1965.

KLEIN, T.M.; GRADZIEL, T., FROMM, M. E.; SANFORD, J. C. Factors influencing gene delivery into Zea mays cells by high-velocity microprojectiles. Bio/Technology, n.6, p.559-563, 1988.

HANSEN, G.; DAS, A.; CHILTON, M.D. Constitutive expression of the virulence genes improves the efficiency of plant transformation by Agrobacterium. Proceedings of the National Academy of Sciences of the United States of America, v.91, n.16, p.7603-7607. 1994.

HANSEN, G.; WRIGHT, M.S. Recent advances in the transformation of plants. Trends in Plant Science, v.4, n.6, p.226-231, 1999.

HELLENS, R.; MULLINEAUX, P.; KLEE, H. A guide to Agrobacterium binary Ti vectors. Trends in Plant Science, v.5, n.10, p.446-451, 2000.

HERRERA-ESTRELLA, L.; DEPICKER, A.; VANMONTAGU, M.; SCHELL, J. Expression of chimaeric genes transferred into plant-cells using a Ti-plasmidderived vector. Nature, v.303, n.5914, p.209-213, 1983.

HESS, K.M.; DUDLEY, M.W.; LYNN, D.G.; JOERGER, R.D.; BINNS, A.N. Mechanism of phenolic activation of Agrobacterium virulence genes development of a specific inhibitor of bacterial sensor response systems. Proceedings of the National Academy of Sciences of the United States of America, v.88, n.17, p.7854-7858, 1991.

HO, C.K.; CHANG, S.H.; TSAY, J.Y.; TSAI, C.J.; CHIANG, V.L.; CHEN, Z.Z. Agrobacterium tumefaciens mediated transformation of Eucalyptus camaldulensis and production of transgenic plants. Plant Cell Reports, v.17, n.9, p.675-680, 1998.

HOOD, E.E.; FRALEY, R.T.; CHILTON, M.D. Virulence of Agrobacteriumtumefaciens strain-a281 on legumes. Plant Physiology, v.83, n.3, p.529-534, 1987.

HOOYKAAS, P.J.J.; BEIJERSBERGEN, A.G.M. The virulence system of Agrobacterium-tumefaciens. Annual Review of Phytopathology, v.32, p.157-179, 1994.

HORSCH, R.B.; FRY, J.E.; HOFFMANN, N.L.; EICHHOLTZ, D.; ROGERS, S.G.; FRALEY, R.T. A simple and general-method for transferring genes into plants. Science, v.227, n.4691, p.1229-1231, 1985. 
ISHIDA, Y.; SAITO, H.; OHTA, S.; HIEI, Y.; KOMARI, T.; KUMASHIRO, T. High efficiency transformation of maize (Zea mays L.) mediated by Agrobacterium tumefaciens. Nature Biotechnology, v.14, p.745-750, 1996.

JASPER, F.; KONCZ, C.; SCHELL, J.; STEINBISS, H.H. Agrobacterium Tstrand production in-vitro - sequence-specific cleavage and 5' protection of single-stranded-DNA templates by purified VirD2 protein. Proceedings of the National Academy of Sciences of the United States of America, v.91, n.2, p.694-698, 1994.

JAYASWAL, R.K.; VELUTHAMBI, K.; GELVIN, S.B.; SLIGHTOM, J.L. Doublestranded cleavage of T-DNA and generation of single- stranded T-DNA molecules in Escherichia coli by a virD-encoded border-specific endonuclease from Agrobacterium-tumefaciens. Journal of Bacteriology, v.169, n.11, p.5035-5045, 1987.

JEFFERSON, R.A.; KAVANAGH, T.A.; BEVAN, M.W. Gus fusions - betaglucuronidase as a sensitive and versatile gene fusion marker in higherplants. Embo Journal, v.6, n.13, p.3901-3907, 1987.

JIN, S.G.; PRUSTI, R.K.; ROITSCH, T.; ANKENBAUER, R.G.; NESTER, E.W. Phosphorylation of the VirG protein of Agrobacterium-tumefaciens by the autophosphorylated VirA protein - essential role in biological-activity of VirG. Journal of Bacteriology, v.172, n.9, p.4945-4950, 1990a.

JIN, S.G.; ROITSCH, T.; ANKENBAUER, R.G.; GORDON, M.P.; NESTER, E.W. The VirA protein of Agrobacterium-tumefaciens is autophosphorylated and is essential for vir gene-regulation. Journal of Bacteriology, v.172, n.2, p.525-530, 1990b.

JOERSBO, M.; BRUNSTEDT, J. Sonication - a new method for gene-transfer to plants. Physiologia Plantarum, v.85, n.2, p.230-234. 1992.

JOHN MC, AMASINO RM Expression of an Agrobacterium Ti plasmid gene involved in cytokinin biosynthesis is regulated by virulence loci and induced by plant phenolic compounds. J Bacteriol, v. 170, p.790-795, 1988.

KLEIN, T.M.; GRADZIEL, T.; FROMM, M.E.; SANFORD, J.C. Factors influencing gene delivery into Zea-mays cells by high- velocity microprojectiles. Bio-Technology, v.6, n.5, p.559-563, 1988.

KLEIN, T.M.; WOLF, E.D.; WU, R.; SANFORD, J.C. High-velocity microprojectiles for delivering nucleic-acids into living cells. Nature, v.327, n.6117, p.70-73. 1987. 
LEHMANN, J. F., HERRISCK, J. F. \& KRUSEN, F. H. The effects of ultrasound on chromosomes, nuclei and other structures of the cell. Arch. Phys. Med. Rehab, 1954. p.141-148.

MACHADO, L.D.R.; DEANDRADE, G.M.; CID, L.P.B.; PENCHEL, R.M.; BRASILEIRO, A.C.M. Agrobacterium strain specificity and shooty tumour formation in eucalypt (Eucalyptus grandis $X E$-urophylla). Plant Cell Reports, v.16, n.5, p.299-303, 1997.

MANTELL, S.H.; MATTHEWS, J.A.; MCKEE, R. A. Princípios de biotecnologia em plantas: uma introdução à engenharia genética em plantas. Trad. de J. L. de Azevedo, M. L. R. Aguiar-Perecin e N. A. Vello. Ribeirão Preto: SBG, 1994. 344p.

MATSUMOTO, T.K.; WEBB, D.T.; KUEHNLE, A.R. Histology and origin of somatic embryos derived from Anthurium andraeanum linden ex Andre lamina. Journal of the American Society for Horticultural Science, v.121, n.3, p.404-407, 1996.

MAURO, A.O.; PFEIFFER, T.W.; COLLINS, G.B. Inheritance of soybean susceptibility to Agrobacterium-tumefaciens and its relationship to transformation. Crop Science, v.35, n.4, p.1152-1156, 1995.

MILLER, M.W.; VOORHEES, S.M.; CARSTENS.EL; EAMES, F.A. Histological study of effect of ultrasound on growth of Vicia- faba roots. Radiation Botany, v.14, n.3, p.201-208, 1974.

MORALEJO, M.; ROCHANGE, F.; BOUDET, A.M.; TEULIERES, C. Generation of transgenic Eucalyptus globulus plantlets through Agrobacterium tumefaciens mediated transformation. Australian Journal of Plant Physiology, v.25, n.2, p.207-212, 1998.

MULLINS, K.V.; LLEWELLYN, D.J.; HARTNEY, V.J.; STRAUSS, S.; DENNIS, E.S. Regeneration and transformation of Eucalyptus camaldulensis. Plant Cell Reports, v.16, n.11, p.787-791, 1997.

MUKHOPADHYAY, A.; ARUMUGAM, N.; NANDAKUMAR, P.B.A.; PRADHAN, A.K.; GUPTA, V.; PENTAL, D. Agrobacterium-mediated genetictransformation of oilseed Brassica-campestris: transformation frequency is strongly influenced by the mode of shoot regeneration. Plant Cell Reports, v.11, n.10, p.506-513, 1992.

MURASHIGE, T., SKOOG, F. A revised medium for rapid growth and biomassay with tobacco tissue cultures. Physiol. Plantarum, v.15, 473-497, 1962. 
NAM, J.; MATTHYSSE, A.G.; GELVIN, S.B. Differences in susceptibility of Arabidopsis ecotypes to crown gall disease may result from a deficiency in TDNA integration. Plant Cell, v.9, n.3, p.317-333, 1997.

PORTER, J.R. Host range and implications of plant infection by Agrobacteriumrhizogenes. Critical Reviews in Plant Sciences, v.10, n.4, p.387-421, 1991.

QUOIRIN, M.; VIEIRA, R.C. Rhizogenesis and nodule formation from callus of Eucalyptus grandis and E.grandis $X$ E.urophylla. Arquivos de biologia e tecnologia, v.38, n.3, p.793-798, 1995.

RIKER, A. J., Studies on the influence of some environmental factors on the development of crown gall. J. Agric. Res., v.32, p.83-96, 1926.

RITCHIE, S.W.; LUI, C.N.; SELLMER, J.C.; KONONOWICZ, H.; HODGES, T.K.; GELVIN, S.B. Agrobacterium-tumefaciens-mediated expression of gusa in maize tissues. Transgenic Research, v.2, n.5, p.252-265, 1993.

ROBBS, S.L.; HAWES, M.C.; LIN, H.J.; PUEPPKE, S.G.; SMITH, L.Y. Inheritance of resistance to crown gall in Pisum-sativum. Plant Physiology, v.95, n.1, p.52-57, 1991.

RUSSELL, J.A.; ROY, M.K.; SANFORD, J.C. Physical trauma and tungsten toxicity reduce the efficiency of biolistic transformation. Plant Physiology, v.98, n.3, p.1050-1056, 1992.

SAKAI, W.S. Simple method for differential staining of paraffin embedded plant material using toluidine blue . Stain Technology, v.48, n.5, p.247-249, 1973.

SANFORD, J.C. Biolistic plant transformation. Physiologia Plantarum, v.79, n.1, p.206-209, 1990.

SANFORD, J. C.; DEVIT, M. J.; RUSSELL, J. A.; SMITH, F. D.; HARPENDING, P. R.; ROY, M. K.; JOHNSTON, S. A. An improved, helium-driven biolistic device. Technique, v.3, n.1, p.3-16, 1991.

SANFORD, J.C.; SMITH, F.D.; RUSSELL, J.A. Optimizing the biolistic process for different biological applications. Methods in Enzymology, v.217, p.483509, 1993.

SANGWAN, RS.; BOURGEOIS, S.; VASSEUR, G.; SANGWAN-NORREEL, B. Characterization of competente cells and early events of Agrobacteriummediated genetic transformation in Arabidopsis thaliana. Planta, v.188, p.439-456, 1992. 
SANTAREM, E.R.; TRICK, H.N.; ESSIG, J.S.; FINER, J.J. Sonication assisted Agrobacterium-mediated transformation of soybean immature cotyledons: optimization of transient expression. Plant Cell Reports, v.17, n.10, p.752759, 1998.

SAWAHEL, W.A. Transgenic plants - performance, release and containment. World Journal of Microbiology \& Biotechnology, v.10, n.2, p.139-144, 1994.

SOCIEDADE BRASILEIRA DE SILVICULTURA. Eucalipto no Brasil e no mundo htt://www.floresta.ipef.br (agosto 2000).

SCHEIFFELE, P.; PANSEGRAU, W.; LANKA, E. Initiation of Agrobacteriumtumefaciens T-DNA processing - purified proteins VirD1 and VirD2 catalyze site-specific and strand-specific cleavage of superhelical T-border DNA invitro. Journal of Biological Chemistry, v.270, n.3, p.1269-1276, 1995.

SCHELL, J.; VANMONTAGU, M.; HERNALSTEENS, J.P.; WILLMITZER, L.; LEEMANS, J.; JOOS, H.; OTTEN, L.; DEGREVE, H.; HOLSTERS, M.; ZAMBRYSKI, P.; HERRERA, L.; DEPICKER, A. Transfer and expression of foreign genes in plants. DNA-A Journal of Molecular \& Cellular Biology, v.2, n.2, p.165, 1983.

SCHLAPPI, M.; HOHN, B. Competence of immature maize embryos for Agrobacterium-mediated gene-transfer. Plant Cell, v.4, n.1, p.7-16, 1992.

SCHROEDER, H.E.; SCHOTZ, A.H.; WARDLEYRICHARDSON, T.; SPENCER, D.; HIGGINS, T.J.V. Transformation and regeneration of 2 cultivars of pea (Pisum- sativum I). Plant Physiology, v.101, n.3, p.751-757, 1993.

SERRANO, L.; ROCHANGE, F.; SEMBLAT, J.P.; MARQUE, C.; TEULIERES, C.; BOUDET, A.M. Genetic transformation of Eucalyptus globulus through biolistics: complementary development of procedures for organogenesis from zygotic embryos and stable transformation of corresponding proliferating tissue. Journal of Experimental Botany, v.47, n.295, p.285-290, 1996.

SHEN, W.H.; ESCUDERO, J.; SCHLAPPI, M.; RAMOS, C.; HOHN, B.; KOUKOLIKOVANICOLA, Z. T-DNA transfer to maize cells - histochemical investigation of beta-glucuronidase activity in maize tissues. Proceedings of the National Academy of Sciences of the United States of America, v.90, n.4, p.1488-1492, 1993.

SMARRELLI, J.; WATTERS, M.T.; DIBA, L.H. Response of various cucurbits to infection by plasmid-harboring strains of Agrobacterium. Plant Physiology, v.82, n.2, p.622-624, 1986. 
SMITH, F.D.; HARPENDING, P.R.; SANFORD, J.C. Biolistic transformation of prokaryotes: factors that affect biolistic transformation of very small-cells. Journal of General Microbiology, v.138, p.239-248, 1992.

SMITH, E.F., TOWNSEND, C.O. A plant-tumor of bacterial origin. Science, v.25, p.671-673, 1907.

STACHEL, S.E.; MESSENS, E.; VANMONTAGU, M.; ZAMBRYSKI, P. Identification of the signal molecules produced by wounded plant-cells that activate T-DNA transfer in Agrobacterium- tumefaciens. Nature, v.318, n.6047, p.624-629, 1985.

STACHEL, S.E.; TIMMERMAN, B.; ZAMBRYSKI, P. Generation of singlestranded T-DNA molecules during the initial-stages of T-DNA transfer from Agrobacterium-tumefaciens to plant-cells. Nature, v.322, n.6081, p.706-712, 1986.

STECK, T.R.; LIN, T.S.; KADO, C.I. VirD2 gene-product from the nopaline plasmid ptic58 has at least 2 activities required for virulence. Nucleic Acids Research, v.18, n.23, p.6953-6958, 1990.

SUSLICK, K. HOMOGENOUS SONOCHEMISTRY. In: SUSLICK, K. ed., Ultrasound, its Chemical, Physical, and Biological Effects Weinheim, Germany: VCH Publishers, 1988. p. 123-161.

SVAB, Z.; HAJDUKIEWICZ, P.; MALIGA, P. Stable transformation of plastids in higher-plants. Proceedings of the National Academy of Sciences of the United States of America, v.87, n.21, p.8526-8530, 1990.

TRICK, H.N.; FINER, J.J. SAAT: sonication-assisted agrobacterium -mediated transformation. Transgenic Research, v.6, n.5, p.329-336, 1997.

TRICK, H.N.; FINER, J.J. Sonication assisted agrobacterium-mediated transformation of soybean [Glycine max (L.) Merrill] embryogenic suspension culture tissue. Plant Cell Reports, v.17, n.6-7, p.482-488, 1998.

VANROEKEL, J.S.C.; DAMM, B.; MELCHERS, L.S.; HOEKEMA, A. Factors influencing transformation frequency of tomato (Lycopersicon-esculentum). Plant Cell Reports, v.12, n.11, p.644-647, 1993.

WILMINK, A.; VANDEVEN, B.C.E.; DONS, J.J.M. Expression of the gus-gene in the monocot tulip after introduction by particle bombardment and Agrobacterium. Plant Cell Reports, v.11, n.2, p.76-80. 1992.

WINANS, S.C. 2-way chemical signaling in Agrobacterium-plant interactions. Microbiological Reviews, v.56, n.1, p.12-31, 1992. 
XU, Y.; BU, W.W.; LI, B.J. Metabolic factors capable of inducing Agrobacterium-vir gene- expression are present in rice (Oryza-sativa L). Plant Cell Reports, v.12, n.3, p.160-164,1993.

ZELENIN, A.V.; TITOMIROV, A.V.; KOLESNIKOV, V.A. Genetictransformation of mouse cultured-cells with the help of high-velocity mechanical DNA injection. Febs Letters, v.244, n.1, p.65-67, 1989.

ZHANG, L.J.; CHENG, L.M.; XU, N.; ZHAO, N.M.; LI, C.G.; YUAN, J.; JIA, S.R. Efficient transformation of tobacco by ultrasonication. Bio-Technology, v.9, n.10, p.996-997, 1991.

ZUPAN, J.; ZAMBRYSKI, P. The Agrobacterium DNA transfer complex. Critical Reviews in Plant Sciences, v.16, n.3, p.279-295, 1997. 